\title{
الإسهاه النسبي لعادات العقل في التنبؤ بفاعلية الذات الإبداعية لدى الطلبة الموهوبين
}

\author{
مهند القضاة
}

The Contribution Ratio of Mind's Habits in Predicting Creative Self-Efficacy for Gifted Students

Muhannad Alqudah, Ministry of Education, Jordan.

Abstract: The present study aimed at uncovering the contribution ratio of the mind's habits in predicting creative self-efficacy of gifted students in Jordan, and to find out if there are statistically significant differences in mind's habits and creative self-efficacy attributed to gender and class variables in a cluster sample of (420) gifted students in basic seventh and tenth grades in King Abdullah II Schools of Excellence, Jordan. To achieve the aims of the study, Rodgers' scale for habits of mind and Abbott's scale for creative self-efficacy were used, after verifying their validity and reliability. Results of the study showed that the mean scores for creative self-efficacy in females were higher than in males. Also, the results showed that the mean scores for some habits of students' mind as well as their creative self-efficacy were higher among seventh grade students if compared to 10th graders. Finally, multiple regression analysis results showed that persistence habits, the application of knowledge, thinking and communicating clearly and accurately, along with creativity, imagination and collecting data by using their senses, have contributed effectively in predicting creative selfefficacy

(Keywords: Habits of Mind, Creative Self-efficacy, Gifted Students)

وفي غمرة الاهتمام بتنمية التفكير، وبخاصة تنمية مهارات التفكير

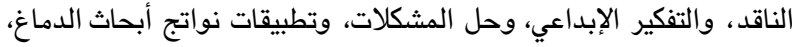

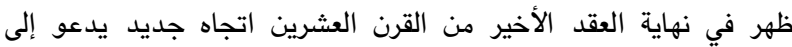

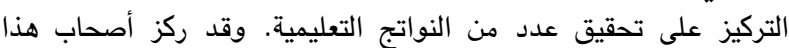

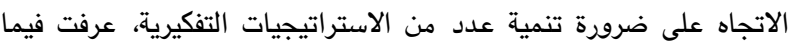

بعد بنظرية عادات العقل (Nofal, 2010).

وتعد عادات العقل (Habits of Mind) من المتغيرات المهمة التي

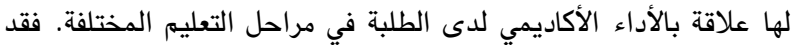

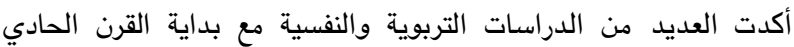

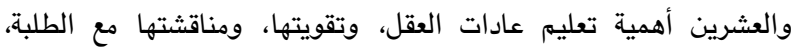
والتفكير فيها، وتقويمها، وتقديم التعزيز اللازم للطلبة من أجل تشات التهيعهمه

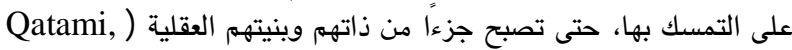

. (2007

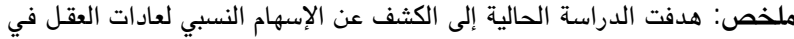

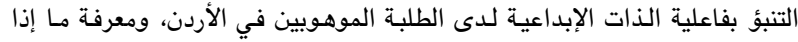

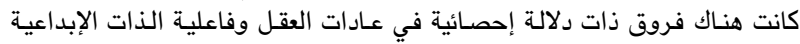

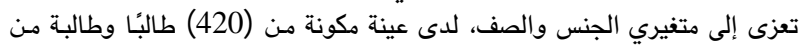

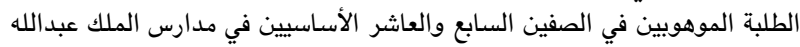

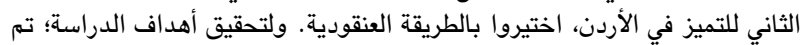

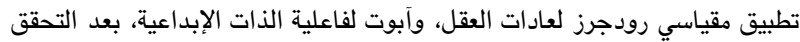

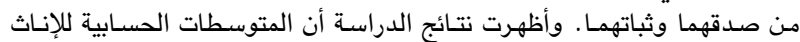

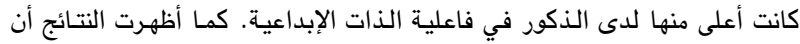

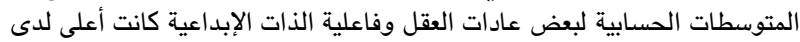

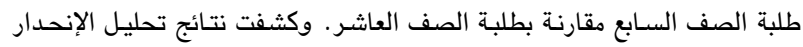

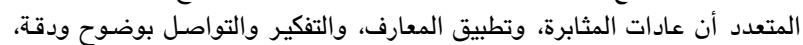

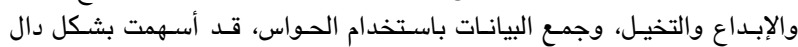
إحصائيًا في التنبؤ بفاعلية الذات الإبداعية .

(الكلمات المفتاحية: عادات العقل، فاعلية الذات الإبداعية، الطلبة الموهوبون)

مقدمـة: إن التغير المتســارع والتطور التكنولوجي الذي يواحهـه

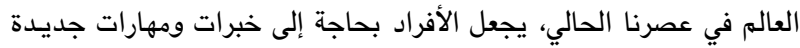

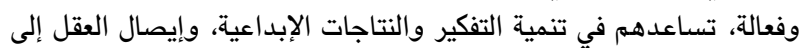

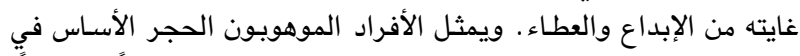

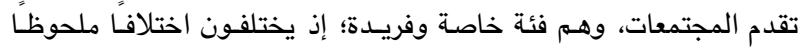

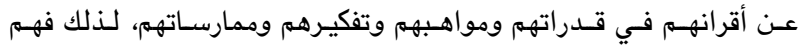

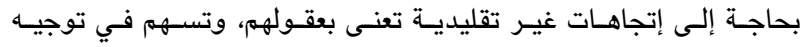
سلوكياتهم الإبداعية، وتساعدهم في تطوير قدراتهم على حل المشكات المكلات.

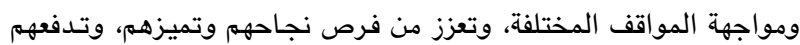

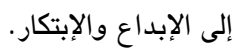

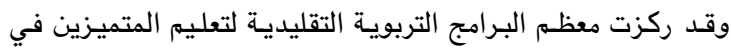

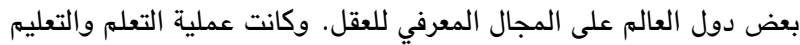

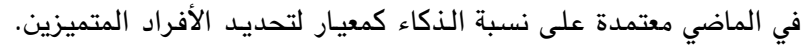

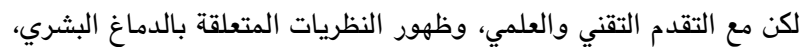

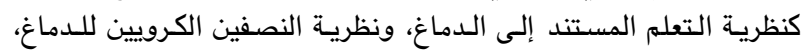

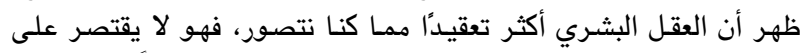

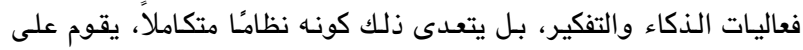
تفاعل المعرفة والانفعال والحواس والإبداع (Huroub, 1999). * وزارة التربية والتعليم- الأردن. (C) حقوق الطبع محفوظة لجامعة اليرموك، اربد، الأردن. 


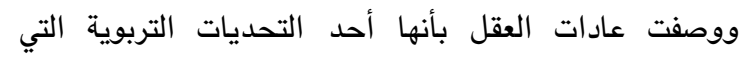
فرضتها التطورات التكنولوجية المتلاحقة في إعداد أفراد لديهم

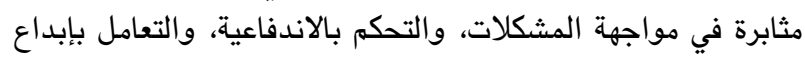

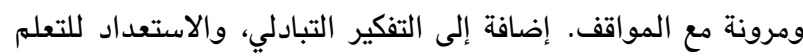

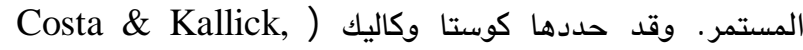
2008) بست عشرة عادة عقلية، كما يلي:

1- المثابرة: قدرة الفرد على الالتزام بالمهمة الموكولة إليه

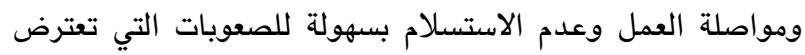

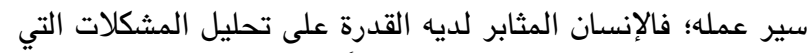

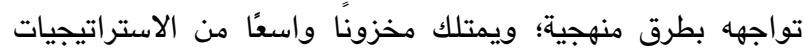

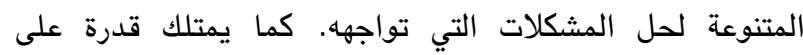

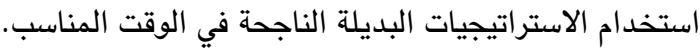

2- التفكير والتواصل بوضوح ودقة: قدرة الفرد على تهذيب اللغة وتوصيل ما يريد قوله بوضوح ودقة، سواء أكان ذلك كتابيًا أم

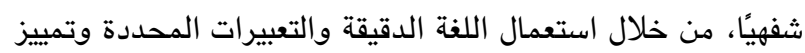
التشابهات والاختلافات، والقدرة على صنع قرارات أكثر شمولية،

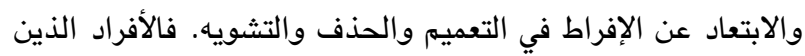

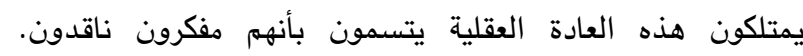

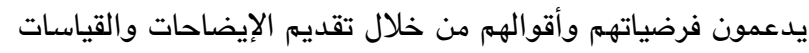
الكمية والأدلة المقبولة.

3- التحكم بالاندفاعية: القدرة على التأني والإصفاء لوجهات

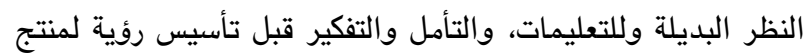
ما أو وضع خطة عمل. وتتضمن القدرة على التأمل في البدائل

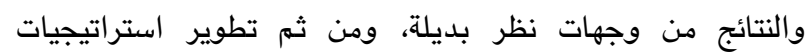

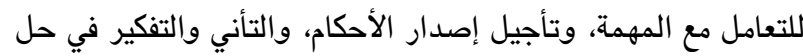
المشكلات قبل إعطاء أحكام متسرعة حول فكرة معينة، والنظر في

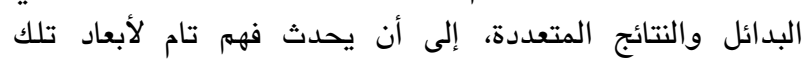

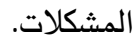

4- التساؤل وطرح المشكلات: قدرة الفرد على طرح الأسئلة،

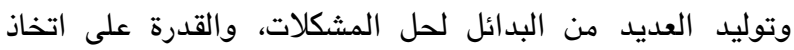

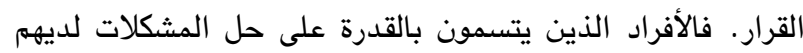

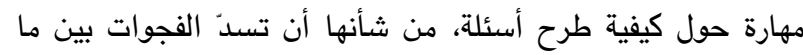
يعرفون وما لا يعرفون.

5- الاستجابة بدهشة ورهبة: قدرة الفرد على الاستمتاع بالبحث

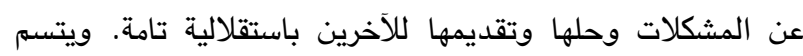

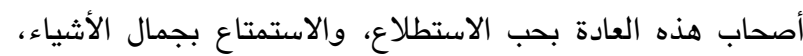
والشعور بالحماس والتحدي، وتقصي الحلول ومواصلة التعاد التعلم.

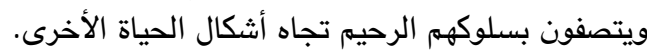

6- التفكير بمرونة: قدرة الفرد على التفكير ببدائل وخيارات وحلول جديدة، ووجهات نظر متعددة، مع طلاقة في الحديث. ويتسهم الفرد الذي يمتلك هذه العادة بالقدرة على تغيير حالته فئه فئه
ويؤكد كامبل (Campbell, 2006) أهمية عادات العقل ودورها في كيفيّة تعلم الطلبة، حيث يرى أنه يمكن اعتبار عادات

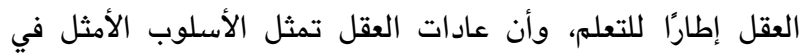

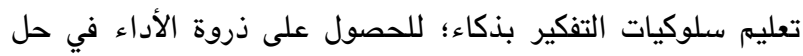

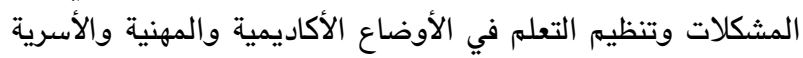

المختلفة .

وجاء الاهتمام بتنمية عادات العقل في إطار تنمية قدرات الموهوبين في توظيف تفكيرهم، بما هو متاح لهم من معارف في

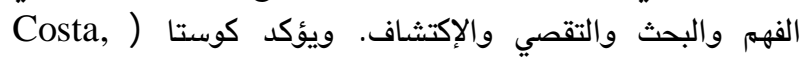
2001) أن إهمال توظيف عادات العقل يؤدي إلى انخفاض مستوى ولإكي

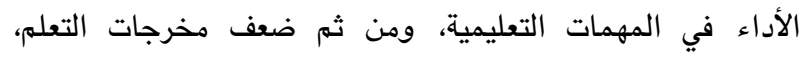
ويثير إلى ضرورة تعليم عادات العقل للطلبة بصورة مباشرة، وفي

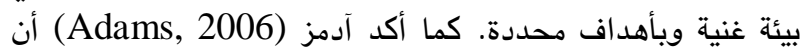
تنمية عادات العقل تحسن مهارات التعلم والفاعلية الذاتية. ويعرف كوستا وكاليك (Costa \& Kallick, 2000) عادات العقل بأنها تركيبة من المهارات والمواقف والخبرات الماضية، تقف وكاليك

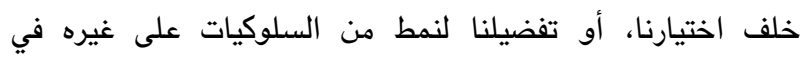

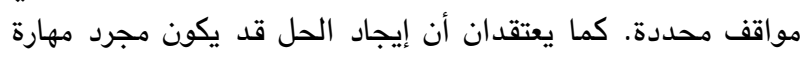

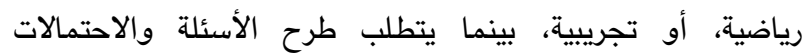
الجديدة والتمعن في مشكلات قديمة من زوايا جديدة خيالاً خلاقًا ويبشر بتقدم حقيقي.

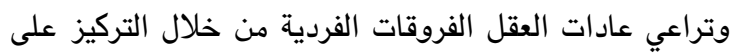

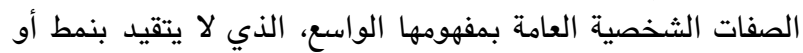

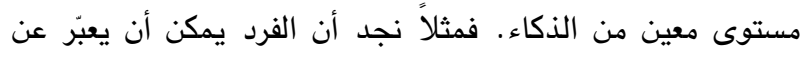

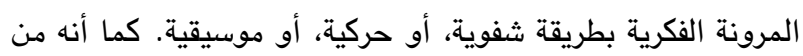

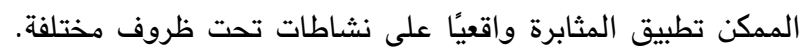

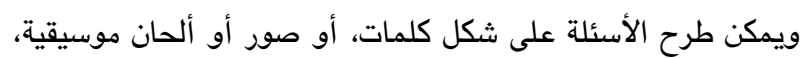

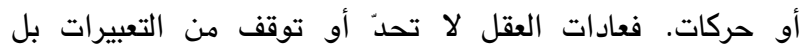

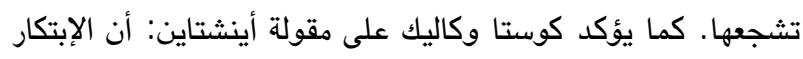

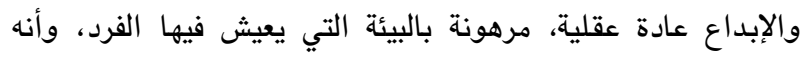

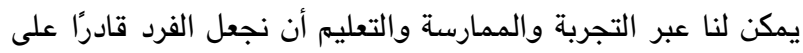

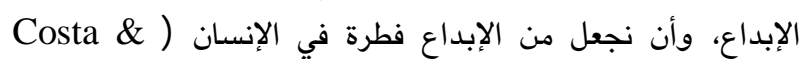
. (Kallick, 2008

وتركز النظم التقليدية في التعليم على النتاجات المحددة ذات

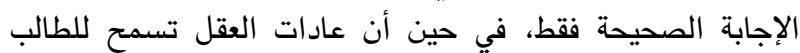

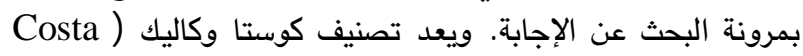
(\& Kallick, 2000

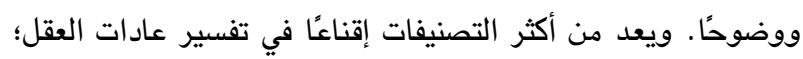

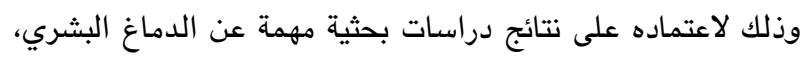

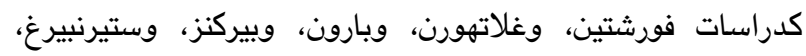
ونموذج أبعاد التعلم لمارزانو . وغلين. 
13- الإبداع والتخيل والتجديد: قدرة الفرد على الارتقاء

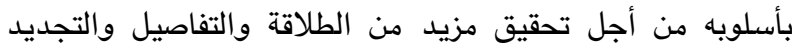

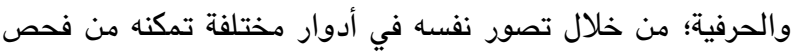

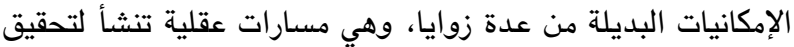

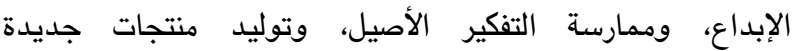
واستخدام أساليب بارعة وحلول ذكية للمشكلات.

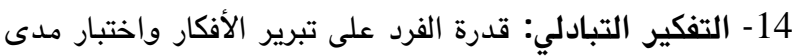

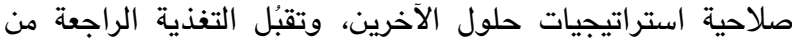

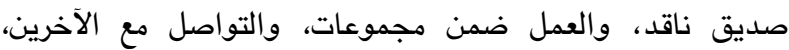
والإحساس تجاه احتياجاتهم. فالأفراد الذين يتسمون بهذه التهات العادئ العقلية يركزون على عمليات التفكير العليا مثل التحليل والتركيب التادي التهاد والتقييم، ولديهم قدرة على فهم كيف يفكر الآخرون، ويقدمون التهي تفسيرات وفرضيات، ويينون أفكارهم على أفكار الآخرين.

15- الاستعداد للتعلم المستمر: قدرة الفرد على التعلم بشكل مستمر وامتلاك الثقة المقرونة بحب الاستطلاع ومواصلة البحث،

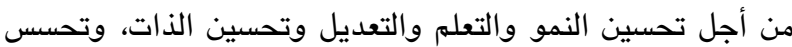

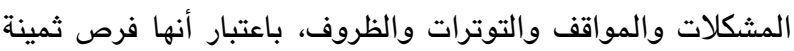
للتعلم. والأفراد الذين يتسمون بهذه العادة العقلية يدركون تمامًا أن الخبرة ليست معرفة كل شيء، بل معرفة مستوى العمل الجديد

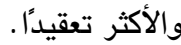

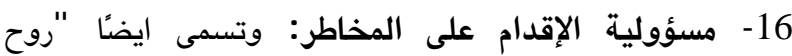

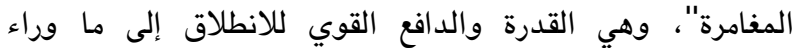
الحدود المستقرة لتجربة استرتيجيات وأساليب وأفكار جديدة الكاليدة وقبول الارتباك والثك، وعدم اليقين، والنظر إلى النكسات على أنها

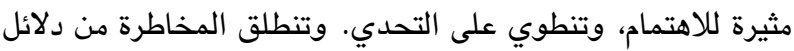

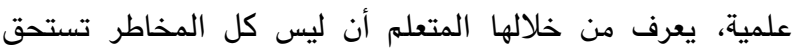

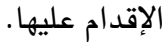

في ضوء مما سبق، يمكن القول إن عادات العقل من

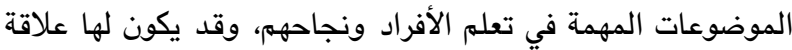

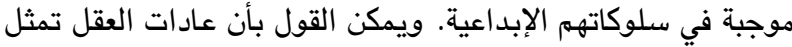

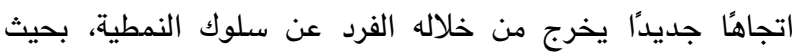

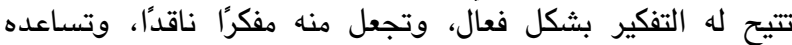

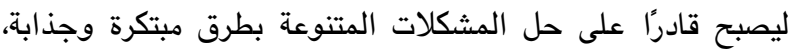
وتحفزه على التعلم المستمر، وتحقيق النجاح والإبداع.

وإذا اعتبرنا أن الإنسان كائن واع واجتماعي بطبعه، فهو أيضًا

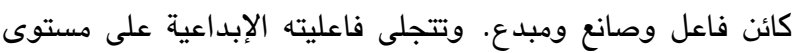

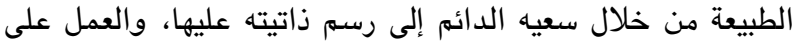

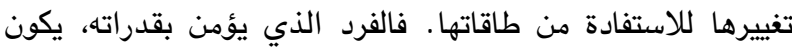

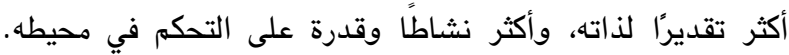
والإنسان الذي لا يثق بنفسه، قد يواجه مشكلات تتعلق بقدرته

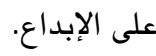

الذهنية عند مواجهة موقف ما أو حل مشكلة معينة. كما تعني هذه

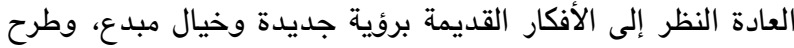
بدائل متعددة عند حل مشكلة واحدة.

7- جمع البيانات باستخدام جميع الحواس: قدرة الفرد على جمع

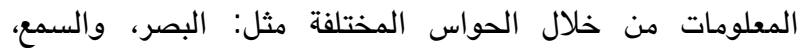

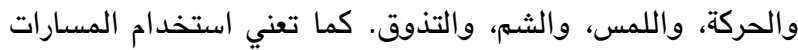

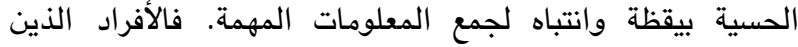

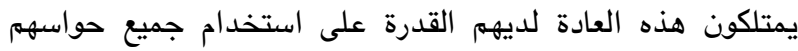
والتحكم بها من أجل تحقيق الفهم والوصول إلى حل للمشكلة التي تواجههم.

8- السعي للدقة: القدرة على العمل المتواصل بحرفية وإتقان دون

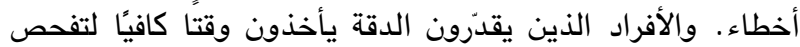

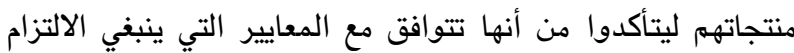

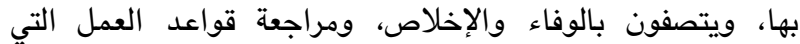
يتعين عليهم إتباعها بإستمرار .

9- تطبيق المعارف السابقة على مواقف جديدة: قدرة الفرد

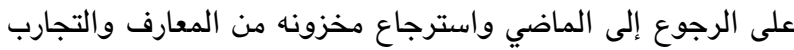

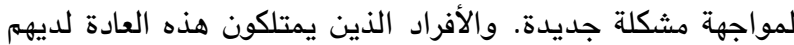

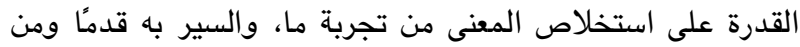

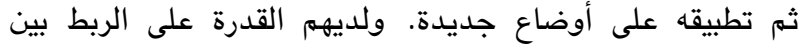

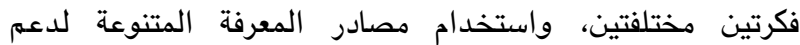

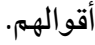

10- الإصفاء بتفهم وتعاطف: القدرة على الإصفاء والتعاطف مع

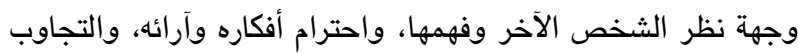

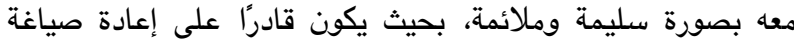

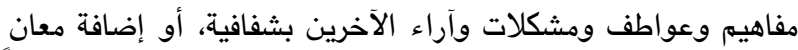

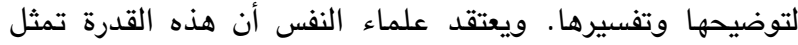

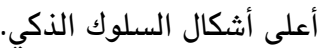

11- التفكير في التفكير (ما وراء المعرفة): قدرة الفرد على الدي إدراك الخطوات اللازمة لخطة عمله، ووصف قدراء الفير التهاته وحاجاته المعرفية، والقدرة على تقييم كفاءة خطته والتخطيط لمهاراته في التفكير، ومدى تأثير أفعاله على ذاته وعلى الآخرين. ويفيد التفكير

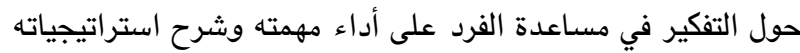
في صنع القرار، وتطوير الخرائط العقلية والتجريب الذهني للتأكد التهاء

من العمل قبل البدء بتنفيذه، ومراقبة الخطط وتقييمها.

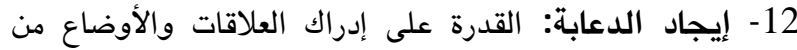
موقع مناسب وأصيل ومثير للاهتمام، واستحسان دعابات الـات الآخرين، والسرور والمتعة والضحك من خلال الانتعاش من تقلب المزاج

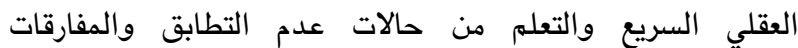
والثغرات. حيث وجد أن الدعابة والمرح تحرر الطاقة للعملية الإبداعية، وتثير مهارات التفكير عالية المستوى. 


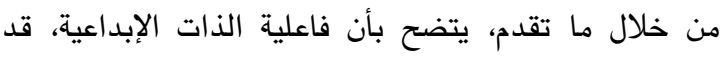

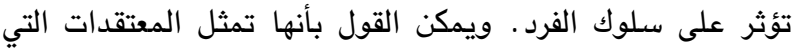

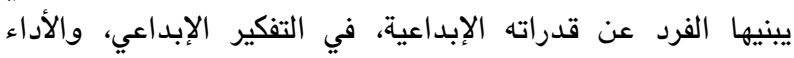

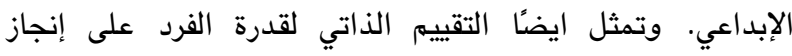

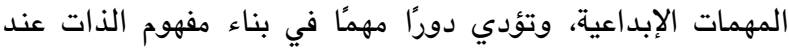
الفرد وتشكيل هويتة الذاتية، وصقل إبداعها.

وتعَّف كلارك (Clark, 2008) الموهبة بأنها مفهوم

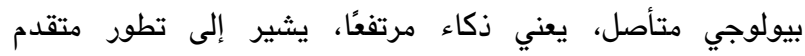

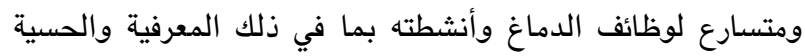

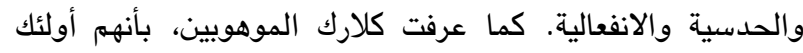

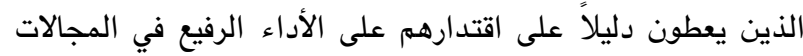

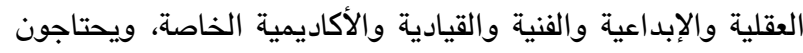
إلى برامج وخدمات وأنشطة من أجل تنمية وتطوير استعداداتهمه. ويصنف ستيرنبرج (Sternberg, 1997) الموهوبين في أربع فئات، كما يلي: • الموهوب تحليليًا: تتجلى موهبته في قدرته على التحليل والنقد

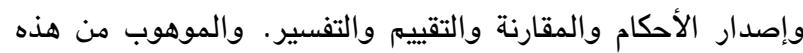
الفئة عادة ما يكون أداؤه في المدرسة جيدًا. • الموهوب إبداعيًا: تظهر موهبته في الاكتثاف، والابتكار والتخيل، ووضع الفرضيات، وتوليد الأفكار.

• الموهوب عمليًا: تظهر موهبته في المهمات العملية التي تتطلب

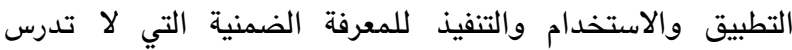

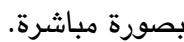

• الموهوب المتوازن: يتمتع هذا الموهوب بمستويات جيدة من القدرات التحليلية والإبداعية والعملية.

وتأسيسًا على ما سبق، نجد أن متغيري عادات العقل وفاعلية

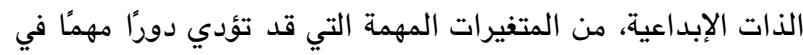

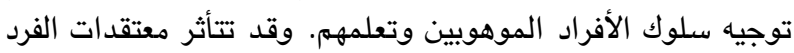

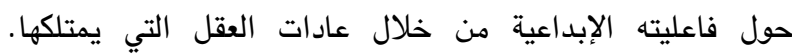

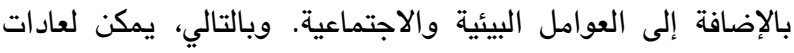

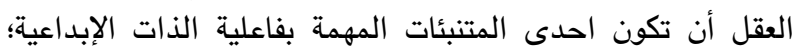

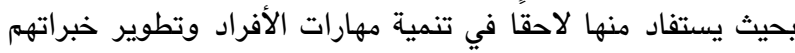

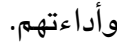

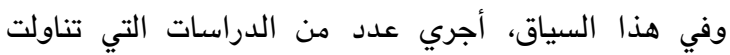

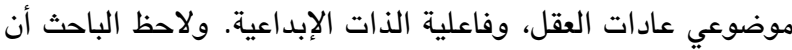

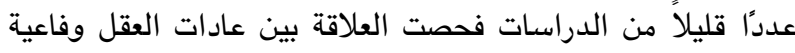

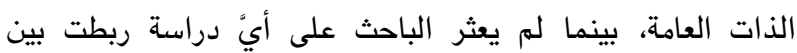

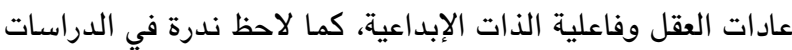

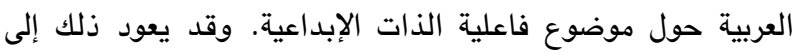

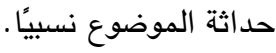

وتمثل الذات مصدر الثخصية التي تكُون ملامح الفرد وتميزه

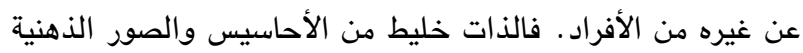

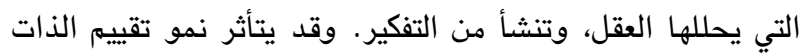

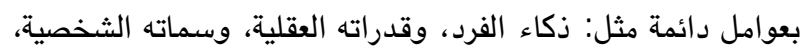

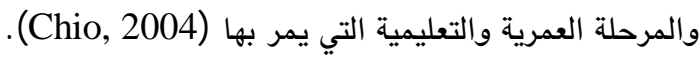
وقد ساهم باندورا (Bandura, 1997) في تقديم نظرية

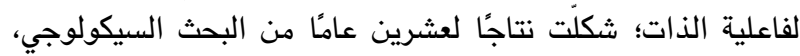

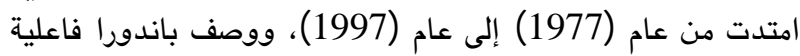

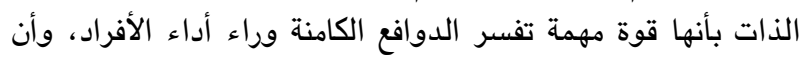

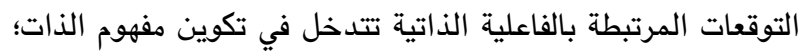

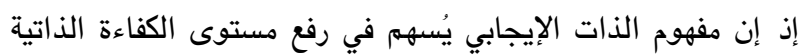

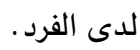

وتعد فاعلية الذات من العوامل المهمة في تحديد النجاح

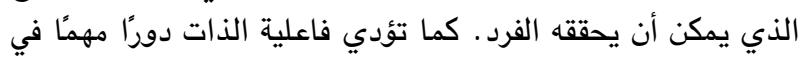

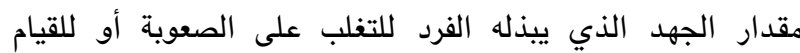

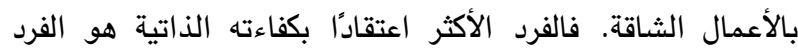
الأكثر تنافسية وقدرة على العمل (Curry, 2007). Creative Self-) كما تعد فاعلية الذات الإبداعية (Efficacy

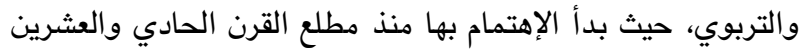

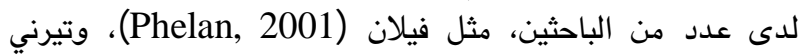

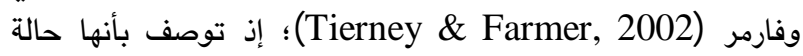

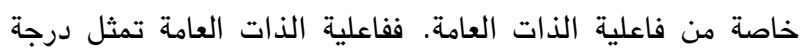

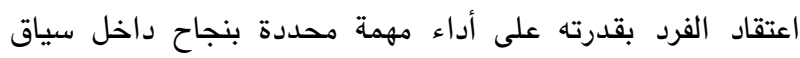

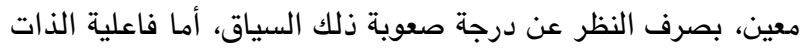

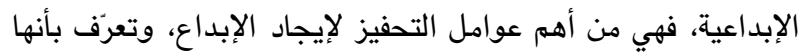

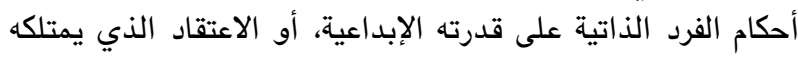

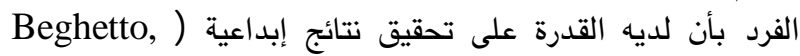

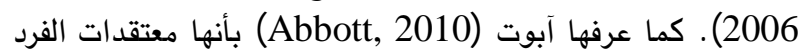

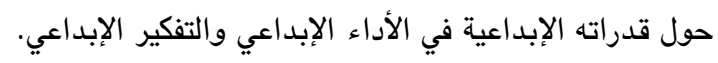

ويعتمد بناء الذات الإبداعية على مستوى الكفاءة الذاتية لدى الفرد، ومدى ثقته بقدراته، وتوقعاته الذاتية حول نالإبدائه نتائج الأعمال

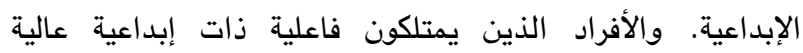

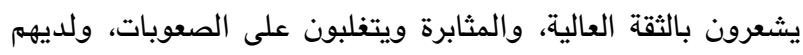

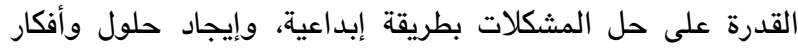

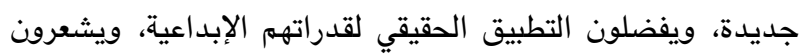

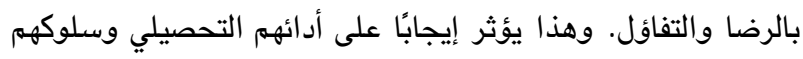

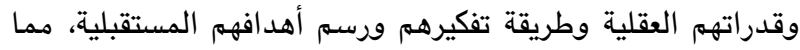
يسه في التغلب على مخاوفهم أثناء ممارسة العملية الإبداعية .(Hsu, Sheng-Tsung \& Hsueh-liang, 2011) 
لدى الطلبة الموهويين. تكونت عينة الدراسة من (360) طالبًا

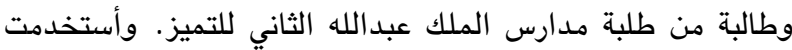
الدراسة مقياس الذكاءات المتعددة ومقياس عادات العات العقل. أظهرت

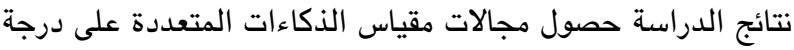

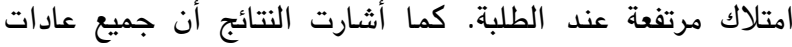

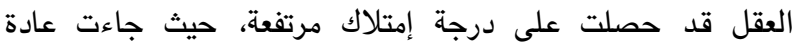

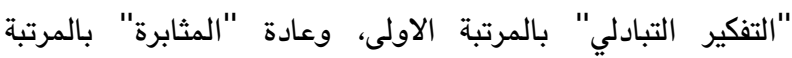

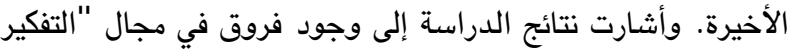

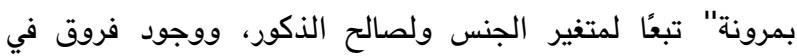

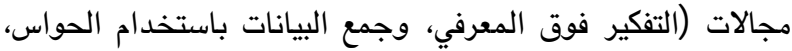

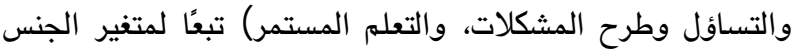

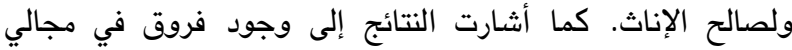

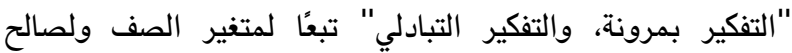
الصف العاشر، ووجود علاقة طردية ذات دلالة إلاتية إحصائية بين معظم مجالات مقياسي الذكاءات المتعددة وعادات العقل.

Nowab \& Hussein, ) وهدفت دراسة النواب وحسين

2013)، إلى فحص الفروق في عادات العقل، والفروق في الفاعلية

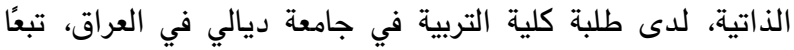

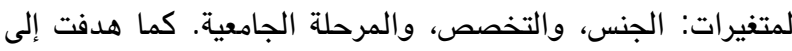
فحص العلاقة بين عادات العقل والفاعلية الذاتية، والعلاقة بين

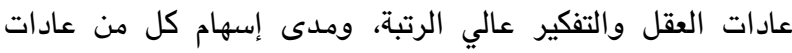

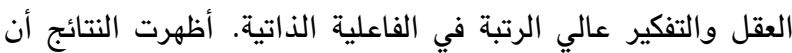

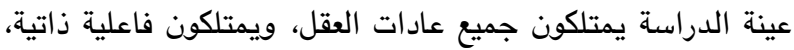

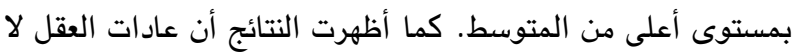

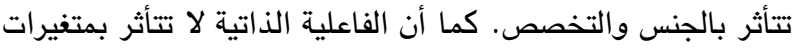

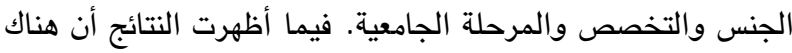

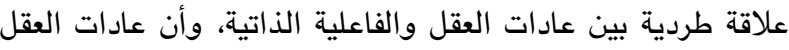
قد أسمهت بشكل دال إحصائيًا في الفاعلية الذاتية.

كما أجرى مرجان والقضاة (Morgan \& Qudah, 2016) دراسة في اليمن، هدفت إلى الكثف عن الإسهام النسبي لعادات

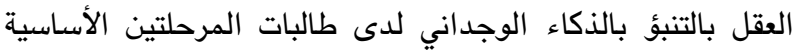

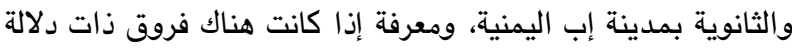

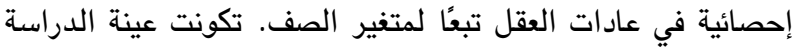

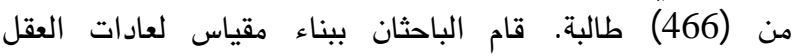
واستخدام مقياس الذكاء الوجداني لبارن-أون. توصلت نتائج الدراسة إلى أن مستوى امتلاك طالبات الدات المرحلتين الأساسية

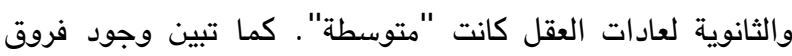

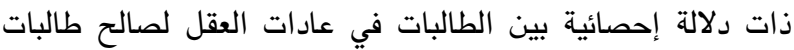

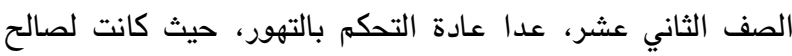

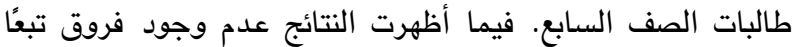

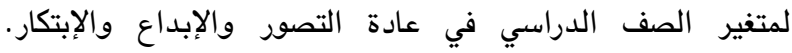

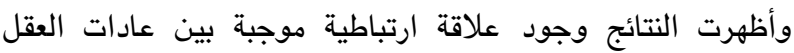

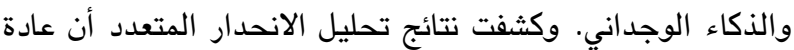

فقد أجرى دوستل (Dostal, 2000) دراسة في ولاية

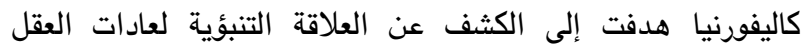

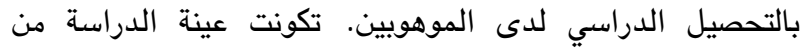

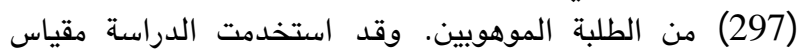

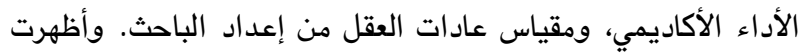

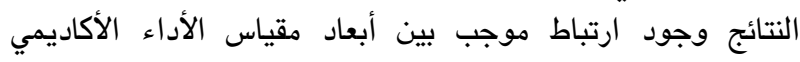

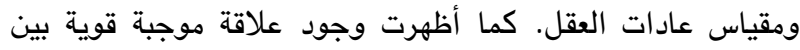
عادات العقل والتحصيل الدراسي. وقام نوفل (Nofal, 2006) بدراسة هدفت الى استقصاء

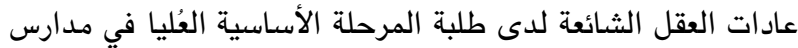

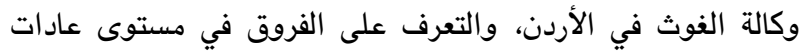

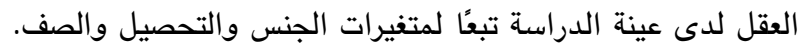

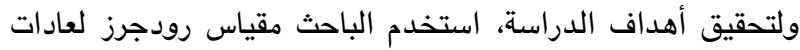

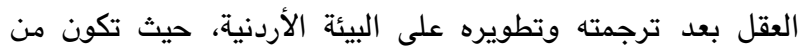

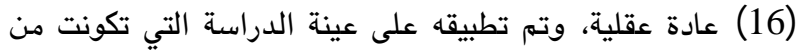
(834) طالبًا وطالبة من طلبة صفوف العاشر، والتاسع، والثامن الثان.

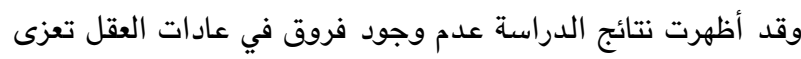

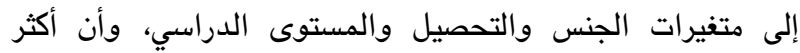

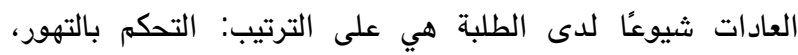

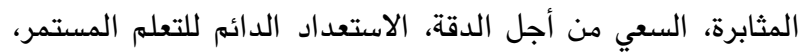
التفكير التبادلي، الإصغاء بتفهم وتعاطف.

وأجرى حجات (Hajjat, 2008) دراسة في الأردن هدفت إلى الكثف عن درجة امتلاك عادات العقل والفاعلية الذاتية لدى الادن هدى

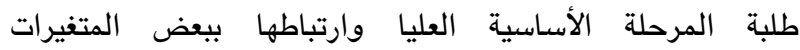

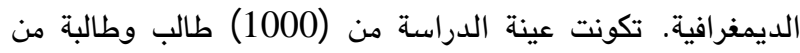

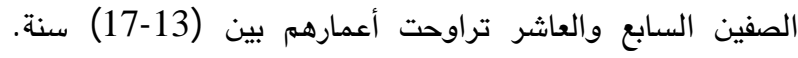

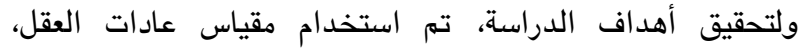

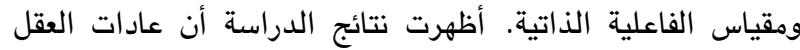

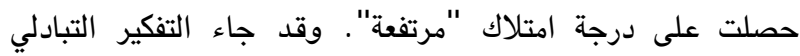

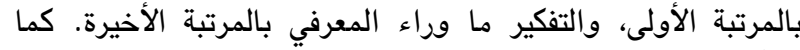

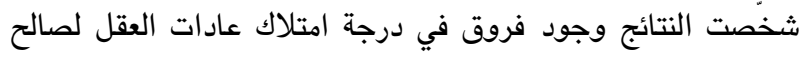

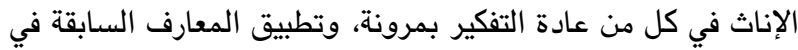

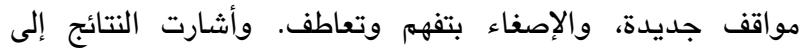

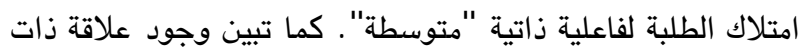
دلالة إحصائية بين عادات العقل والفاعلية الذاتية، حيث بلغ الغاعل معامل الارتباط (0.72). كما تيين أن هناك علاقة إرتباطية موجبة بين

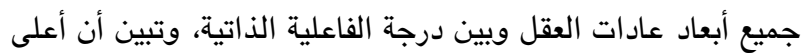

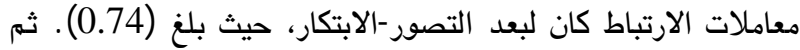

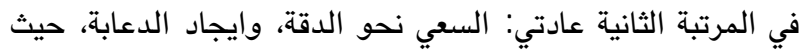
بلغ معامل الارتباط لكل من هاتين العادتين (0.73) . وكان القان أقلها لبعد التفكير بمرونة، حيث بلغ معامل الارتباط (0.50) . وأجرى حجيرات (Hjairat, 2012) دراسة في الأردن، هدفت إلى التعرف على الذكاءات المتعددة وعلاقتها بعادات العقل 
Shih-Ching \& Shy-Yi, ) وأجرى شيتشينج وتشي ياي 2012) دراسة في تايوان، هدفت إلى الكثفي الكاي عن دافعية التعلم والسلوك الابتكاري ودور فاعلية الذات الإبداعية كمتغير وسيط.

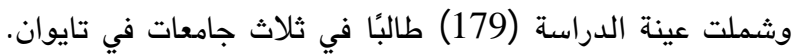

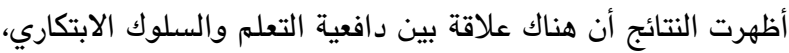
وفاعلية الذات الإبداعية توسطت هذه العلاقة، ووجود علاقة بين التاكين دافعية التعلم وفاعلية الذات الإبداعية. وفي دراسة أجراها ميتثيجي (Maciej, 2012)، هدفت إلى مؤى

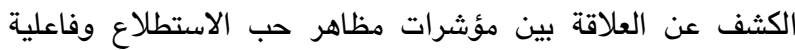

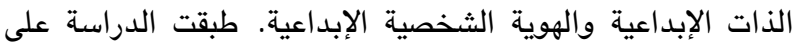

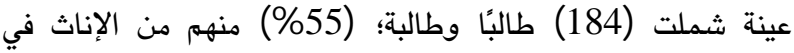

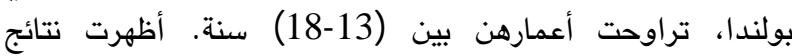
الدراسة وجود علاقة قوية بين حب الاستطلاع المرتفع وبين فاعلية الإنداية الذات الإبداعية والهوية الشخصية الإبداعية. وهدفت دراسة الزعبي (Zoubi, 2014) إلى التحقق من الإنس

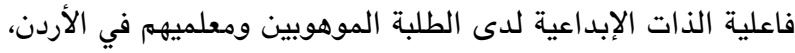

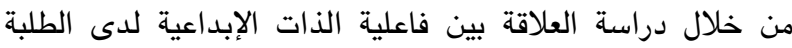
والمعلمين، ومدى اختلافها باختلاف جنسهم وصفوفهمه الدراسية،

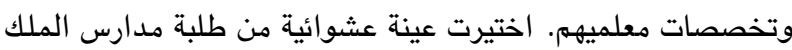

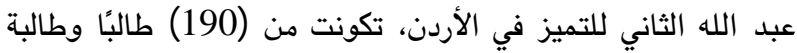

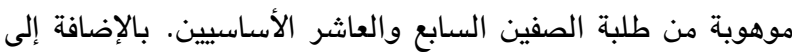

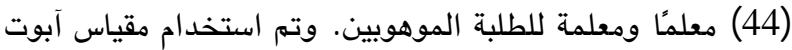
لفاعلية الذات الإبداعية بعد تطويره على البيئة (Abbott, 2010) الأردنية. أشارت النتائج إلى أمتلاك الطلبة الماتليد الموهويين ومعلميهمه

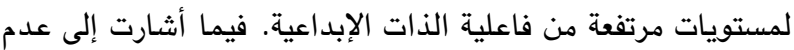

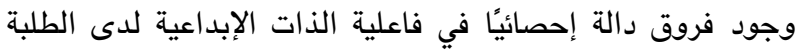

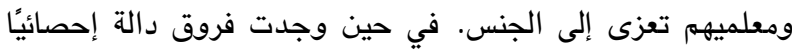

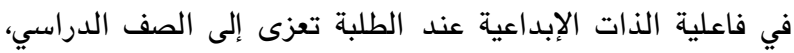

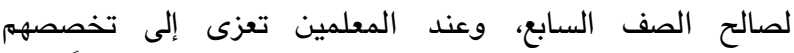
الأكاديمي، لصالح ذوي التخصص العلمي. كما كثفت فروقاً دالة التئ

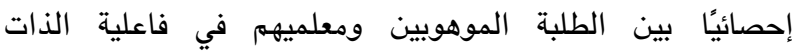

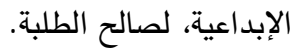

يلاحظ من الدراسات السابقة المتعلقة بفاعلية الذات الإبداعية

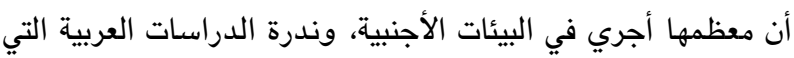

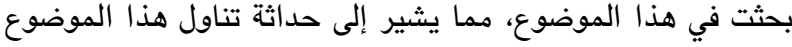

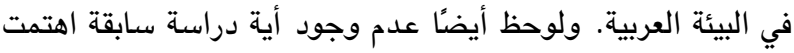

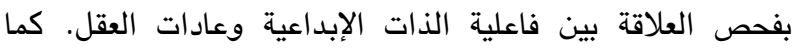

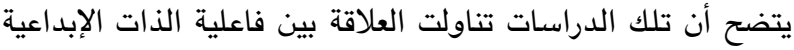

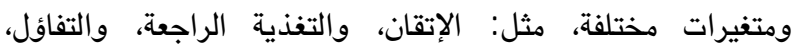

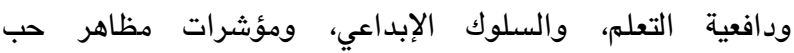
الاستطلاع، والهوية الثخصية الإبداعية.
الإصفاء بتفهم وتعاطف للآخرين، قد أسهمت بشكل دال إحصائيًا في التنبؤ بالذكاء الوجداني. يلاحظ من العرض السابق للدراسات السابقة المتعلقة بعادات العقل أنها تناولت العلاقة بين عادات العقل ومتفيرات مثل: العاتل التحصيل الدراسي، والفاعلية الذاتية، والذكاءات المتعددة، والذكاء

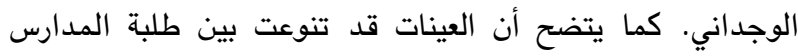

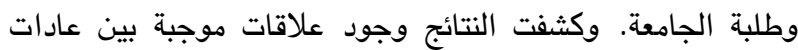

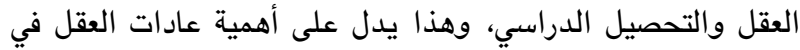

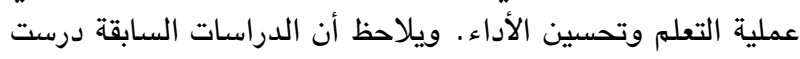

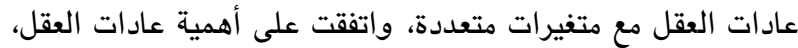

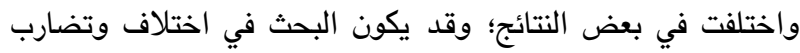

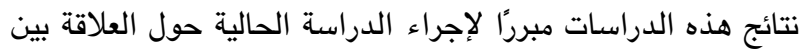
متغيري عادات العقل وفاعلية الذات الإبداعية.

وبالرجوع إلى الدراسات المتعلقة بفاعلية الذات الإبداعية،

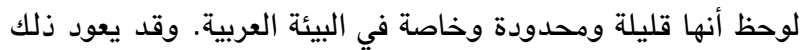

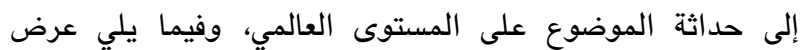
لبعض الدراسات التي تم التوصل إليها:

فقد أجرى بيغيتو (Beghetto, 2006) دراسة هدفت إلى الى الكثف عن العلاقة بين فاعلية الذات الإبداعية والتوجه نحو الاتقان

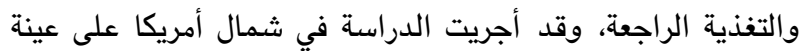

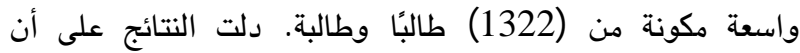

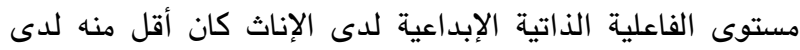

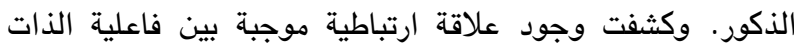

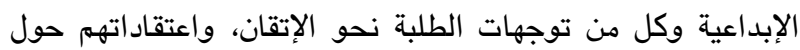

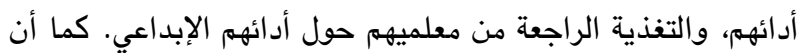

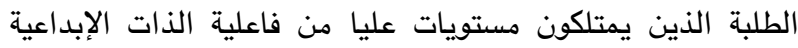

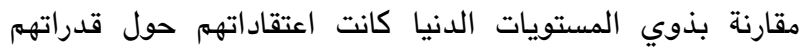
الأكاديمية أعلى في جميع المجالات الدراسية. بالإضافة إلى أنهم

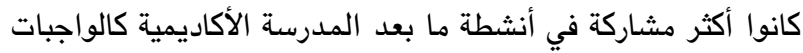

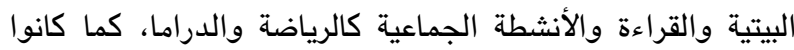
أكثر تصميمًا على الالتحاق بالجامعات بعد مرحلة المدرسة.

Hsu, Sheng-Tsung \& Hsueh-) وقام هسيو وزملاؤ (Liang, 2011

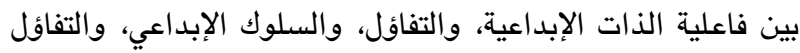

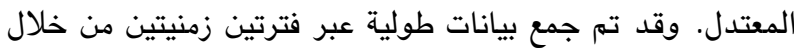

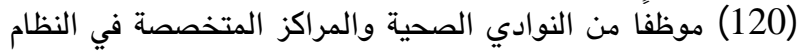

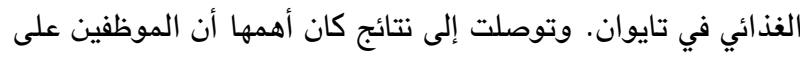

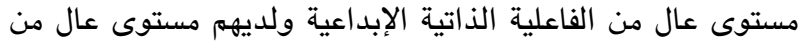

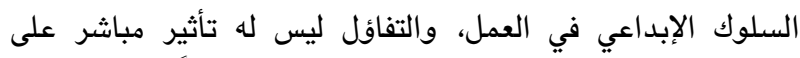

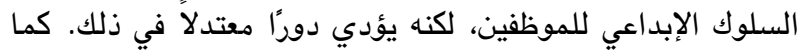

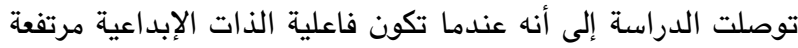
فإن المتفائلين يكون لديهم سلوك إبداعي كبير في العمل. 
2. هل توجد فروق دالة إحصائيًا (م=0.05) في فاعلية الذات

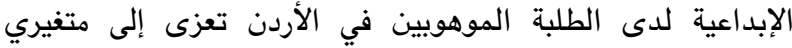
الصف الدراسي (السابع، العاشر) والجنس، والتفاعل بينهما؟ الإن 3. ما درجة الإسهام النسبي لعادات العقل في التنبؤ بفاعلية الذات

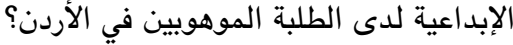

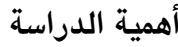

تتمثل أهمية الدراسة الحالية في الجانب النظري، من خلال

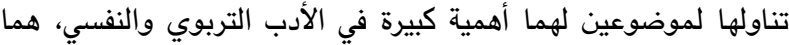

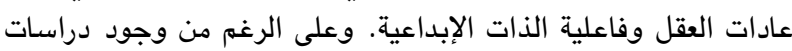

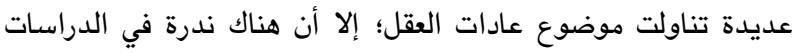

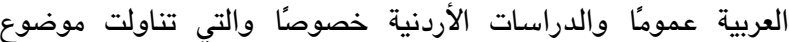

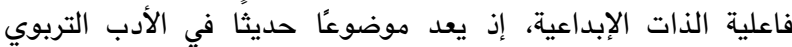

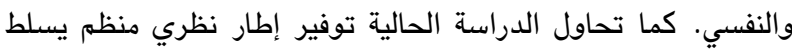
الضوء على أهمية عادات العقل وفاعلية الذات الإبداعية عند الطلبة الطالية

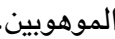

أما الأهمية العملية والتطبيقية للدراسة الحالية، فتتمثل في

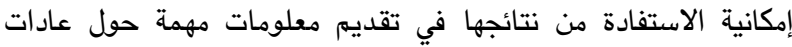

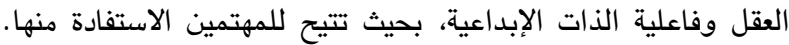

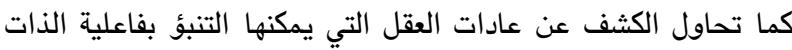

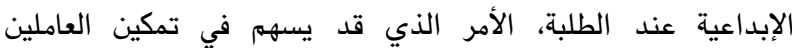
ومتخذي القرار في المؤسسات التعليمية من التعرف إلى طبيعة العلاقة الإنة

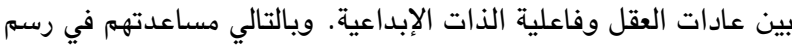

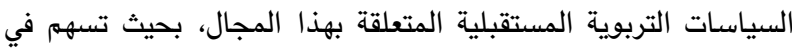

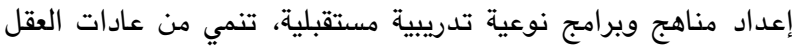

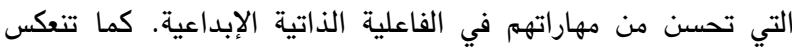

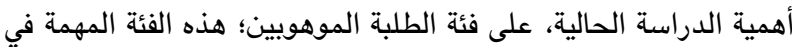

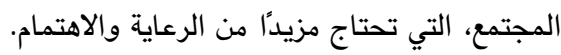

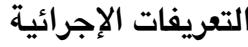

• عادات العقل (Habits of Mind): مجموعة من المهارات والمواتف والخبرات الماضية، وتقف خلف تفضيلنا لنمط من السلوكيات

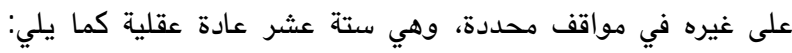

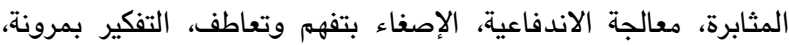

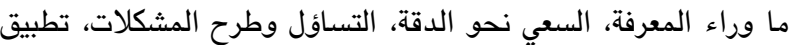

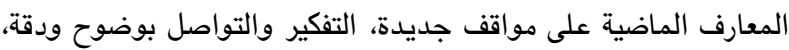

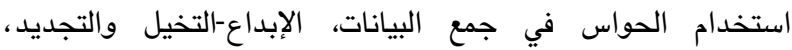

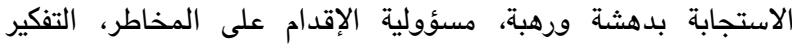

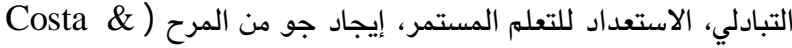

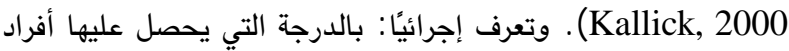
عينة الدراسة على مقياس عادات العقل المستخدم في الدراسة الحالية. • فاعلية الذات الإبداعية (Creative Self-Efficacy): معتقدات

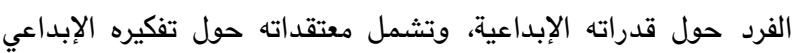

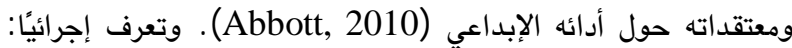

ومن خلال ما تم عرضه، من الدراسات السابقة المتعلقة بعادات العقل وفاعلية الذات الإبداعية؛ يلاحظ أهمية هذين الهاتئ

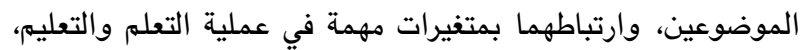

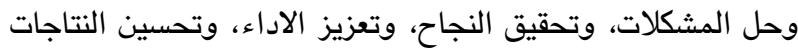
الإبداعية. ولكن الدراسات حول عادات العقل وإسهامها في فاعلية

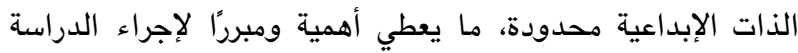

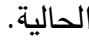

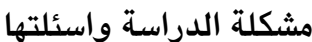

تمثل فئة الطلبة الموهويين جزءا أساسيًا في تطور

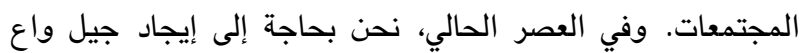

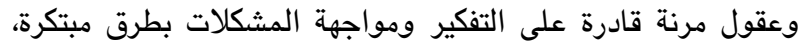
وبحاجة إلى مهارات ذاتية تدفع الأفراد إلى مزيد من الإنجاز ـ ويهذا

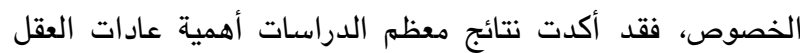

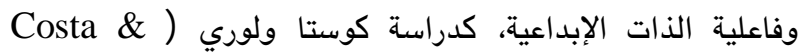
(Lowery, 1991

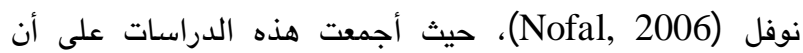

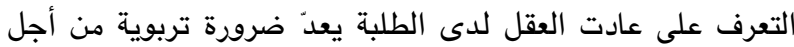

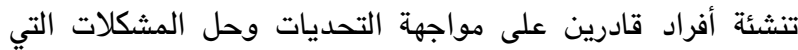

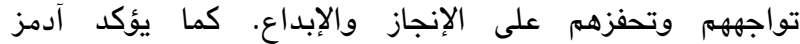
(Adams, 2006)

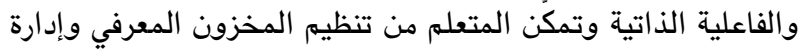

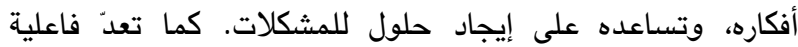

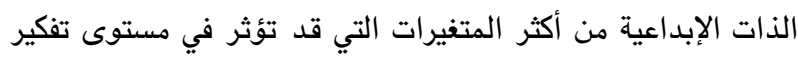

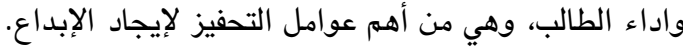
ومن خلال اطلاع الباحث على الدراسات السابقة والأدب الإب الإدابة النظري، لم يجد أنموذجًا يحدد العلاقة بين فاعلي العلية الذات الذات الإبداعية

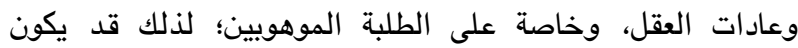

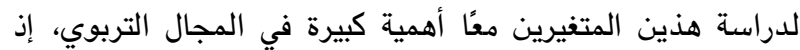

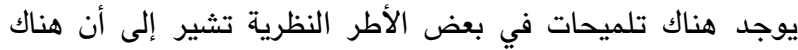

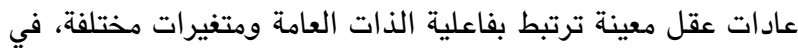

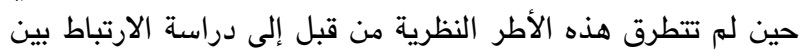

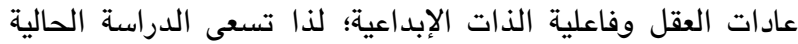

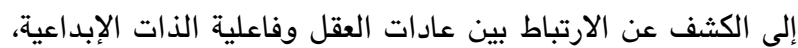

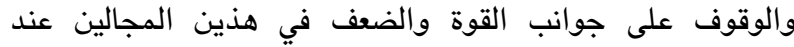

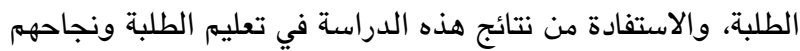

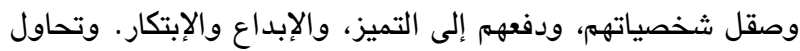
الدراسة الحالية تحديدًا الإجابة عن الاسئلة الآتية: 1. هل توجد فروق دالة إحصائيًا (ل0.05) في عادات العقل

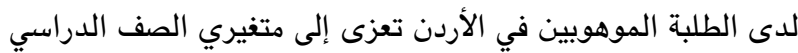
(السابع، العاشر) والجن، والتفاعل بينهما؟ 
للتميز، التابعة لمديريات التربية والتعليم في (10) محافظات

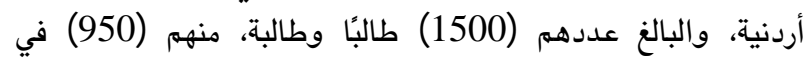

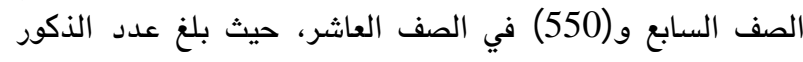
(782) طالبًا، وبلغ عدد الإناث (718) طالبة.

\section{عينة الدراسة}

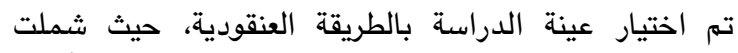

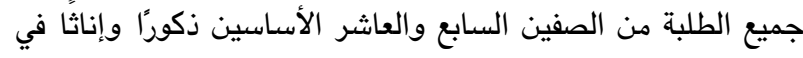

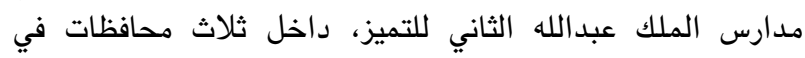

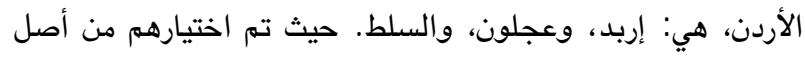

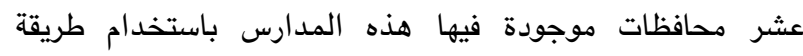

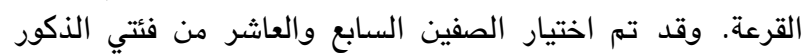

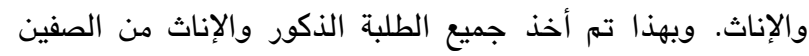

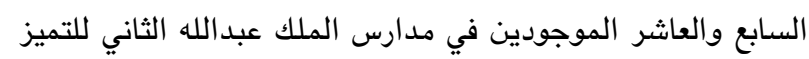

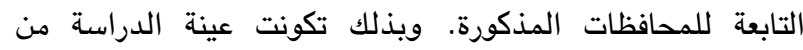

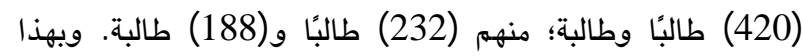

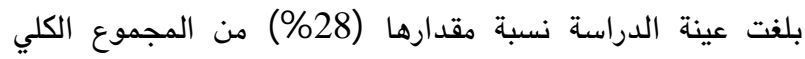

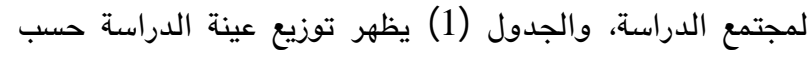
متغيري الجنس والصف.
بالدرجة التي يحصل عليها أفراد عينة الدراسة على مقياس فاعلية الذات الإبداعية المستخدم في الدراسة الحالية. • الطلبة الموهوبون (Gifted Students) : طلبة الصفين السابع

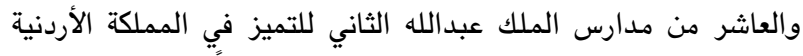

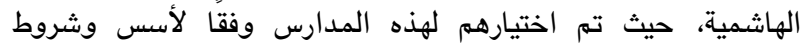

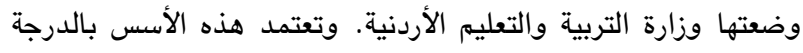

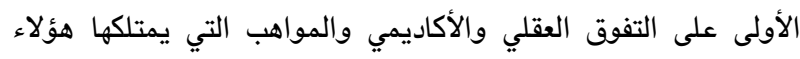

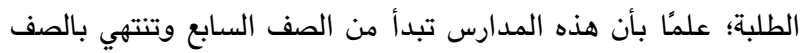

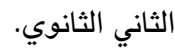
حدود الدراسة ومحدداتها اقتصرت الدراسة الحالية على عينة من طلبة الصفين السابع

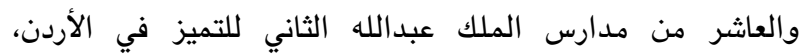

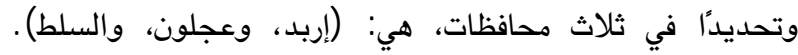

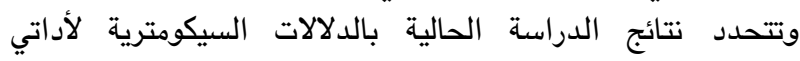

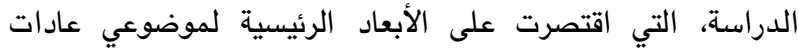
العقل وفاعلية الذات الإبداعية.

$$
\text { مجتمع الدراسة }
$$

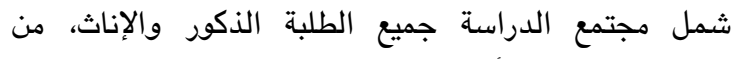
الصفين السابع والعاشر الأساسيين، في مدارس الملك عبدالله الثاني

جدول (1): توزيع عينة الدراسة وفقًا لمتفيري الجنس والصف

\begin{tabular}{|c|c|c|c|}
\hline مجموع أفراد العينة & العاشر & السـابع & الجنس/ الصف \\
\hline 232 & 63 & 169 & الذكور \\
\hline 188 & 72 & 116 & الإناث \\
\hline 420 & 135 & 285 & المجموع الكلي \\
\hline
\end{tabular}

\section{ثانيًا: مقياس فاعلية الذات الإبداعية}

استخدم في الدراسة الحالية مقياس فاعلية الذات الإبداعية

الذي أعده آبوت (Abbott, 2010) وطوره الزعبي (

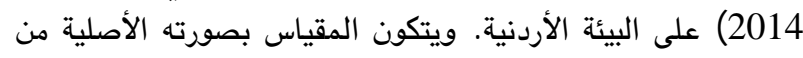

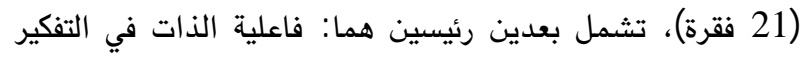

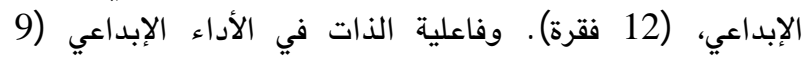
فقرات) . (الابداعي، صدق أداتي الدراسة وثباتهما يتمتع مقياس عادات العقل بصورته الأصلية بدلالات صدق

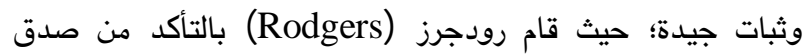

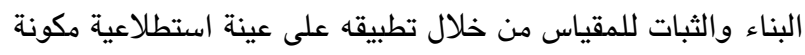

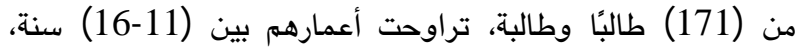

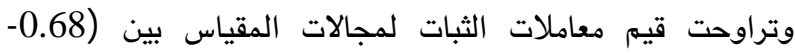

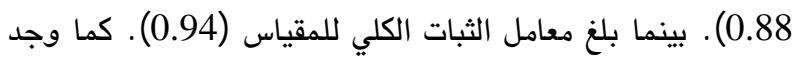

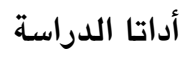
لأغراض تحقيق أهداف الدراسة الحالية؛ استخدمت أداتان

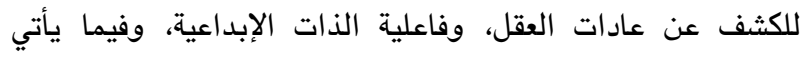
وصف لهاتين الأداتين: أولاً: مقياس عادات العقل من أجل تحقيق أهداف الدراسة الحالية، استخدم مقياس

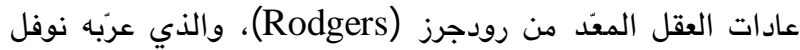

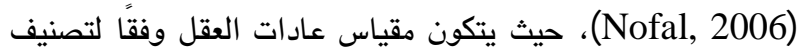

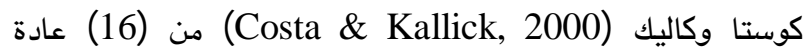

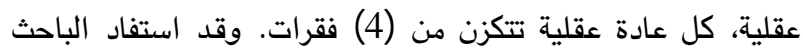

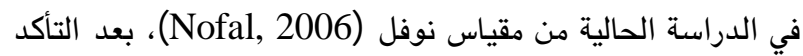

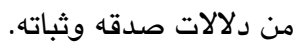


وبالنسبة لمقياس فاعلية الذات الإبداعية؛ فقد تراوحت قيم معاملات ارتباط الفقرة مع البعد بين (0.279-0.619)، بينما فئها تراوحت قيم معاملات الارتباط بين الفقرات والمقياس ككل بين

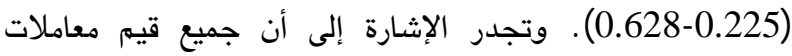

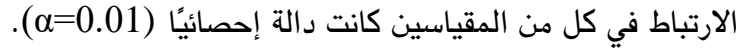

ثبات أداتي الدراسة الحالية

للتحقق من ثبات كل من مقياس عادات العقل ومقياس فاعلية

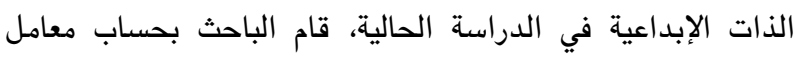
كرونباخ ألفا للأبعاد والمقياس ككل. حيث تبين في مقياس عادات

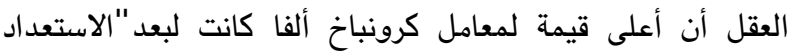
الدائم للتعلم المستمر"، حيث إعلى بلفت (0.76)، وكانت أدنى قيمة

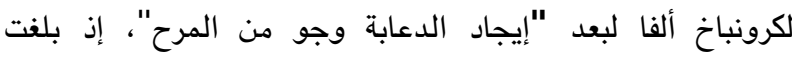
(0.63) . كما بلفت قيمة كرونباخ للمقياس ككل (0.90) . أما بالنسبة لمقياس فاعلية الذات الإبداعية، فقد بلغ معامل الثبات للمقياس الكلي (0.75)، وبلغ (0.68) لبعد فاعلية الذات

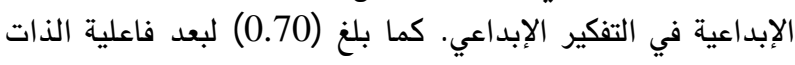

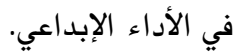

تصحيح مقياس عادات العقل

يتكون مقياس عادات العقل في الدراسة الحالية من (64)

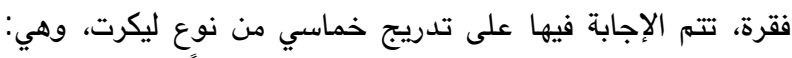

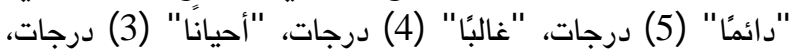

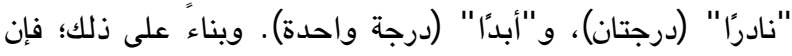

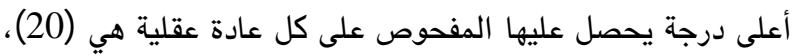
وأدنى درجة يحصل عليها المفحوص هي (4) .

تصحيح مقياس فاعلية الذات الإبداعية يتكون مقياس فاعلية الذات الإبداعية في الدراسة الحالية من

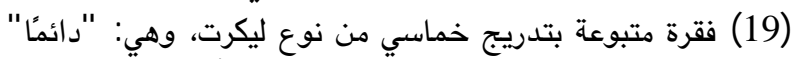

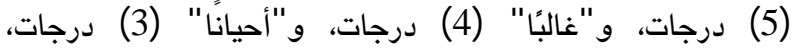

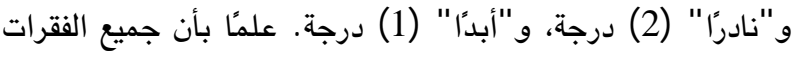

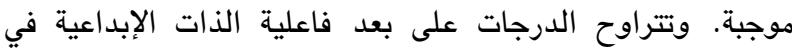

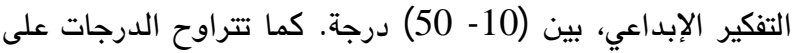

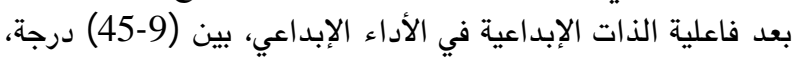
وبذلك تتراوح الدرجات على فاعلية الذات الإبداعية الكلية بين الإبداعل بلدين

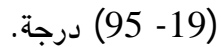

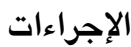

تم الاتصال بالمدارس المعنية، في محافظات (إربد وعجلون

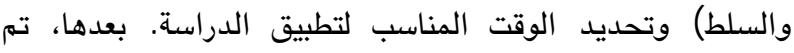

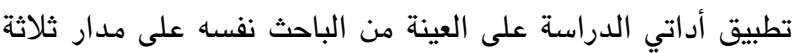

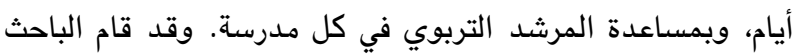

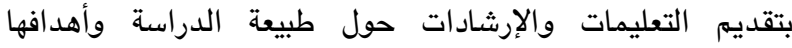
وأهميتها للطلبة. كما تم توضيح طريقة الإجابة للطلبة، والتأكيد على ضرورة موضوعية الإجابة وسرية التعامل مع البيانات.
نوفل (Nofal, 2006) دلالات صدق وثبات جيدة لمقياس عادات العقل بعد تطويره على البيئة الأردنية؛ إذ بلغ معامل الاتساق الداخلي للمقياس (0.85)، وبلغ معامل الثبات للمقياس (0.83) . وبالنسبة لمقياس فاعلية الذات الإبداعية؛ فقد وجد الزعبي (Zoubi, 2014) على البيئة الأردنية، حيث تراوحت قيم معاملات الارتباط بين (0.24)

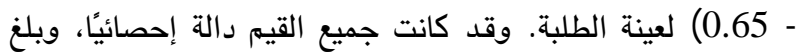
معامل ثبات الإعادة (0.87) . أما معامل الثبات بطريقة الاتساق الداخلي باحتساب معادلة كرونباخ ألفا على التطبيق الأول، فبلغ الألغ التهل (0.91) . وفي الدراسة الحالية، قام الباحث بالتحقق من الدلالات السيكومترية لأداتي الدراسة، من خلال الأدلة الآتية: صدق أداتي الدراسة الحالية

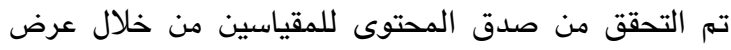

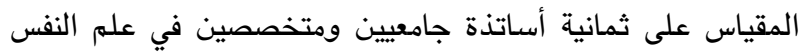

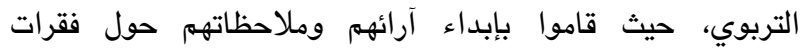
المقياسين ومدى تناسبها وتوافقها مع كل مجال تنتمي إليه. وفي

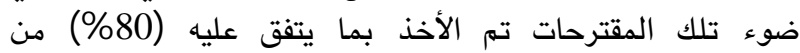
المحكمين لقبول الفقرات واجراء التعديلات المقترحة. وتم اعتماد معيار اتفاق ستة محكمين للحكم على صلاحية بقاء الفقرة ضمن

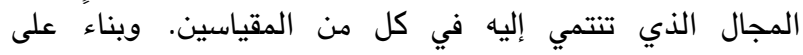

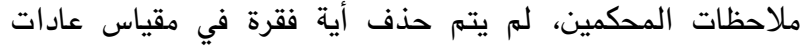
العقل، ويذلك حافظ المقياس على عدد فقراته البالغة (64) فقرة. فيما أشارت اقتراحات المحكمين إلى تغيير بعض الصياغات اللفوية؛ لتتناسب والمعنى الذي يعبر عن المجال الذي تنتمي إليه، وبما يتوافق مع طبيعة عينة الدراسة. ومن جهة أخرى، اتفق المحكمون على إبقاء جميع الفقرات

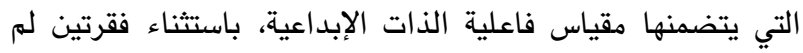

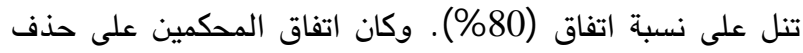
هاتين الفقرتين لأنهما تحملان معاني متقاربة مع فقرات أخرى.

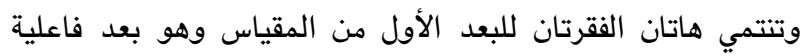

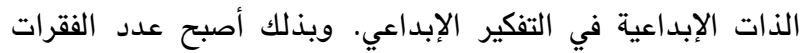

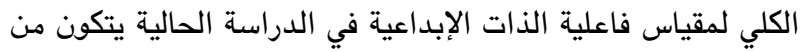

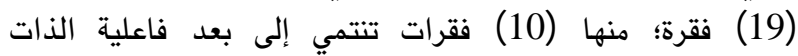

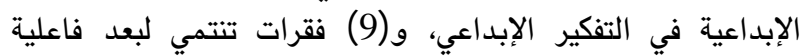
الذات الإبداعية في الأداء الإبداعي.

كما تمّ التحقق من صدق الاتساق الداخلي للأداتين بايجاد

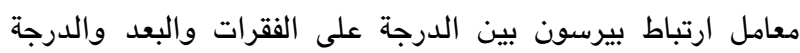

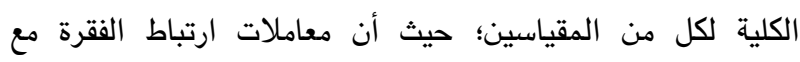
المجال الذي تنتمي إليه تراوحت بين (0.318-0.922) لمقياس عادات العقل. فيما تراوحت قيم معاملات الارتباط بين الفقرات والمقياس ككل بين (0.227-0.641) . 
للإجابة عن هذا السؤال، تم حساب المتوسطات الحسابية

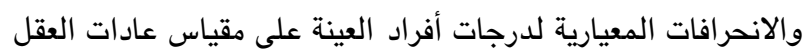

الكلي وأبعاده المختلفة في ضوء متفيرات الدراسة، والجدول (2)

نتائج السؤال الأول: هل توجد فروق دالة إحصائيا

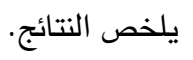

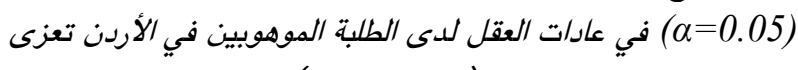

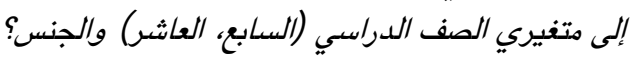

جدول (2): المتوسطات الحسابية والانحرافات المعيارية لاستجابات أفراد العينة على الدرجة الكلية لمقياس عادات العقل تبعًا لمتغيري الجنس والصف

\begin{tabular}{|c|c|c|c|c|}
\hline الانحراف & المستوسطي الحسبي & العدد & الصف & المتغيرات \\
\hline .436 & 4.21 & 169 & السـابع & \multirow{2}{*}{ زكر } \\
\hline .469 & 4.06 & 63 & العاشر & \\
\hline .465 & 4.38 & 116 & السـابع & \multirow{2}{*}{ انثى } \\
\hline .481 & 4.14 & 72 & العاشر & \\
\hline
\end{tabular}

يتضح من الجدول (2) وجود فروق ظاهرية بين المتوسطات فقد أجري تحليل التباين الثنائي (2-Way ANOVA) للدرجة

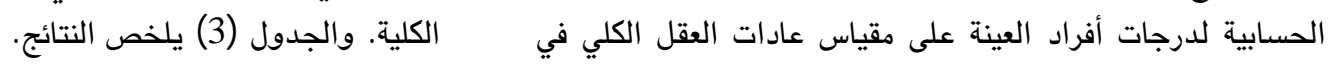
ضوء توزيعها حسب متغيرات الدراسة. ولفحص دلالة هذه الفينة الفروق،

جدول (3): تحليل التباين الثنائي لدرجات أفراد العينة على المقياس الكلي لعادات العقل في ضوء متغيري الجنس والصف

\begin{tabular}{|c|c|c|c|c|c|}
\hline الدلالة & قيمة ف & متوسط مجموع & درجة & مجموع & مصدر \\
\hline الإحصائية & المحسوبة & المربعات & الحرية & المربعات & التباين \\
\hline$* .008$ & 7.110 & 1.484 & 1 & 1.484 & الجنس \\
\hline$* .000$ & 16.889 & 3.525 & 1 & 3.525 & الصف الدراسي \\
\hline \multirow[t]{2}{*}{.338} & .921 & .192 & 1 & .192 & الجنس *الصف الدراسي \\
\hline & & & 419 & 7578.760 & الكلي \\
\hline
\end{tabular}

والانحرافات المعيارية على أبعاد مقياس عادات العقل وفقًا لمتفيري

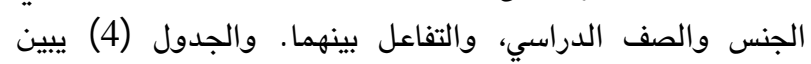

ذلك.
يتضح من الجدول (3) وجود فروق ذات دلالة إحصائية

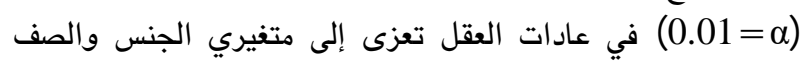

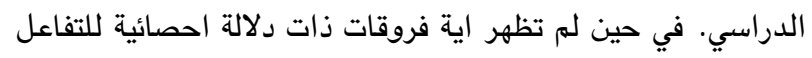
بين الجنس والصف الدراسي. كما تم حساب المتوسطات الحسابية 
جدول (4): المتوسطات الحسابية والانحرافات المعيارية لاستجابة أفراد العينة على أبعاد مقياس عادات العقل وفقًا لمتغيري الجنس والصف

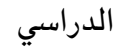

\begin{tabular}{|c|c|c|c|c|c|c|c|}
\hline \multicolumn{6}{|c|}{ الجنس الجس } & \multirow{3}{*}{ الصف } & \multirow{3}{*}{ 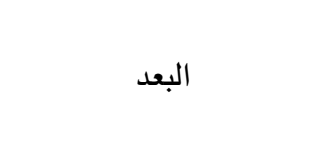 } \\
\hline \multicolumn{3}{|c|}{ الإناث } & \multicolumn{3}{|c|}{ الذكور } & & \\
\hline الانحراف المعياري & المتوسط الحسابي & العدد العد & الانحراف المعياري & المتوسط الحسابي & 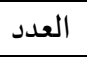 & & \\
\hline .38 & 4.55 & 116 & .62 & 4.40 & 169 & السابع & \multirow{2}{*}{ المثابرة } \\
\hline .56 & 4.36 & 72 & .68 & 4.32 & 63 & العاشر & \\
\hline .54 & 4.15 & 116 & .52 & 4.02 & 169 & 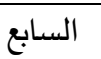 & التفكير والتواصل بوضوح \\
\hline .55 & 3.91 & 72 & .68 & 3.82 & 63 & العاشر & ودقة \\
\hline 1.75 & 4.80 & 116 & .68 & 4.37 & 169 & السابع & \multirow{2}{*}{ التحكم بالاندفاعية } \\
\hline .66 & 4.21 & 72 & .69 & 4.24 & 63 & العاشر & \\
\hline .53 & 4.50 & 116 & .66 & 4.35 & 169 & 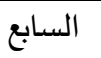 & \multirow{2}{*}{ التساؤل وطرح المشكلات } \\
\hline .66 & 4.42 & 72 & 1.39 & 4.34 & 63 & العاشر & \\
\hline .47 & 4.41 & 116 & .71 & 4.26 & 169 & السابع & \multirow{2}{*}{ الاستجابة بدهشة و رهبة } \\
\hline .72 & 4.16 & 72 & .78 & 4.01 & 63 & العاشر & \\
\hline .55 & 4.29 & 116 & .60 & 4.21 & 169 & 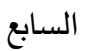 & \multirow{2}{*}{ التفكير بمرونة } \\
\hline 1.03 & 4.23 & 72 & .68 & 4.13 & 63 & العاشر & \\
\hline .49 & 4.36 & 116 & .63 & 4.23 & 169 & السابع & \multirow{2}{*}{ جمع البيانات باستخدام } \\
\hline .59 & 4.27 & 72 & .72 & 4.01 & 63 & العاشر & \\
\hline .56 & 4.27 & 116 & .64 & 4.08 & 169 & السابع & \multirow{2}{*}{ السعي للدقة } \\
\hline .59 & 3.96 & 72 & .66 & 3.99 & 63 & العاشر & \\
\hline .58 & 4.34 & 116 & .61 & 4.17 & 169 & السابع & \multirow{2}{*}{ تطبيق المعارف الماضية } \\
\hline .52 & 4.16 & 72 & .66 & 4.11 & 63 & العاشر & \\
\hline .49 & 4.36 & 116 & .64 & 4.20 & 169 & 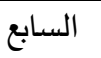 & \multirow{2}{*}{ الإصغاء بتفهم وتعاطف } \\
\hline .72 & 4.10 & 72 & .65 & 4.09 & 63 & العاشر & \\
\hline 2.84 & 4.31 & 116 & .83 & 3.86 & 169 & السابع & \multirow{2}{*}{ التفكير ما وراء المعرفي } \\
\hline .70 & 3.75 & 72 & .65 & 3.70 & 63 & العاشر & \\
\hline .53 & 4.34 & 116 & .56 & 4.18 & 169 & 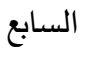 & \multirow{2}{*}{ إيجاد الدعابة وجو من } \\
\hline 1.73 & 4.26 & 72 & .72 & 4.10 & 63 & العاشر & \\
\hline .68 & 4.30 & 116 & .87 & 4.26 & 169 & السابع & \multirow{2}{*}{ الإبداع - التخيل والتجديد } \\
\hline .81 & 4.12 & 72 & .79 & 4.01 & 63 & العاشر & \\
\hline .52 & 4.46 & 116 & .61 & 4.30 & 169 & 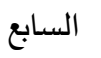 & \multirow{2}{*}{ التفكير التبادلي } \\
\hline .72 & 4.13 & 72 & .79 & 4.02 & 63 & العاشر & \\
\hline .59 & 4.45 & 116 & .70 & 4.33 & 169 & السابع & الإستعداد الدائم للتعلم \\
\hline .82 & 4.17 & 72 & .69 & 4.09 & 63 & العاشر & المستمر \\
\hline .65 & 4.25 & 116 & .75 & 4.14 & 169 & السابع & مسؤولية الإقدام على \\
\hline .73 & 4.00 & 72 & .86 & 3.93 & 63 & العاشر & المخاطر \\
\hline
\end{tabular}

2-Way ) إجراء تحليل التباين الثنائي متعدد المتفيرات التابعة) (SANOVA MANOVA
يظهر من الجدول (4) وجود فروق ظاهرية بين المتوسطات

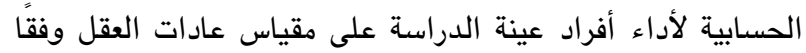
لاختلافات الجنس والصف الدراسي. وللتحقق من دلالة الفروق، تم 
جدول(5): نتائج تحليل التباين الثنائي متعدد المتغيرات على أبعاد مقياس عادات العقل

\begin{tabular}{|c|c|c|c|c|c|c|}
\hline الإحصائية الدلالة & درجة & الفرضية & قالكيمة ف المحسوبة & الاختبار & الاختبار & المتفير \\
\hline .328 & 402.000 & 16.000 & 1.126 & .045 & Hotelling's Trace & الجنس \\
\hline .001 & 402.000 & 16.000 & 2.554 & .102 & Hotelling's Trace & الصف الدراسي \\
\hline .387 & 401.000 & 16.000 & 1.065 & .043 & Hotelling's Trace & الجنس*الصف الدراه \\
\hline
\end{tabular}

وللتحقق من دلالة الفروق على أبعاد مقياس عادات العقل، تم

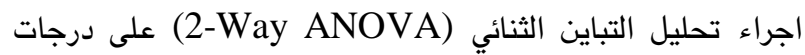
أفراد العينة على أبعاد مقياس عادات العقل، والجدول (6) يظهر

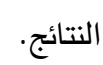

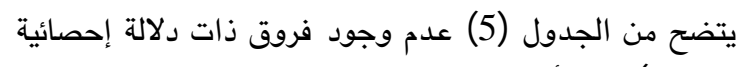

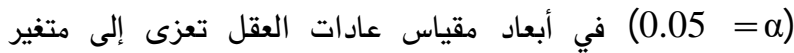

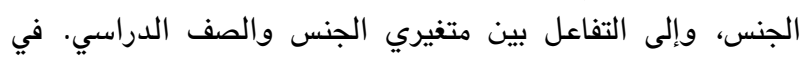

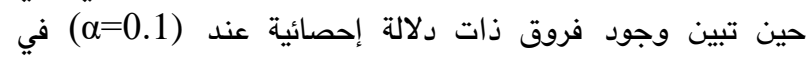
مقياس عادات العقل تعزى إلى متغير الصف الدراسي.

جدول(6) : نتائج تحليل التباين الثنائي لدرجات أفراد العينة على أبعاد مقياس عادات العقل

\begin{tabular}{|c|c|c|c|c|c|c|}
\hline الإحصائية & 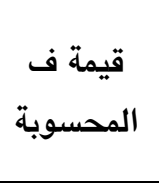 & مجوسط المربعات & 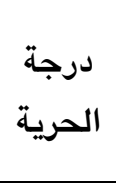 & 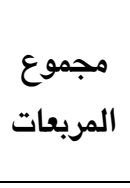 & الت التفير & 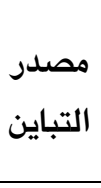 \\
\hline .114 & 2.503 & .798 & 1 & .798 & المثابرة & \\
\hline .067 & 3.382 & 1.049 & 1 & 1.049 & التفكير والتواصل بوضوح ودقة & \\
\hline .079 & 3.106 & 3.665 & 1 & 3.665 & التحكم بالاندفاعية & \\
\hline .151 & 2.068 & 1.270 & 1 & 1.270 & التساؤل وطرح المشكلات & \\
\hline .034 & 4.517 & 2.021 & 1 & 2.021 & الاستجابة بدهشة و رهبة & \\
\hline .224 & 1.482 & .714 & 1 & .714 & التفكير بمرونة & \\
\hline .002 & 9.716 & 3.534 & 1 & 3.534 & جمع الييانات باستخدام جميع الحواس & \\
\hline .211 & 1.570 & .598 & 1 & .598 & السعي للدقة & \\
\hline .071 & 3.266 & 1.159 & 1 & 1.159 & تطبيق المعارف الماضية على مواقف & 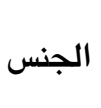 \\
\hline .189 & 1.730 & .667 & 1 & .667 & الإصفاء بتفهم وتعاطف & \\
\hline .148 & 2.105 & 5.579 & 1 & 5.579 & التفكير ما وراء المعرفي & \\
\hline .087 & 2.946 & 2.334 & 1 & 2.334 & إيجاد الدعابة وجو من المرح & \\
\hline .385 & .755 & .486 & 1 & .486 & الإبداع - التخيل والتجديد & \\
\hline .042 & 4.143 & 1.691 & 1 & 1.691 & التفكير التبادلي & \\
\hline .166 & 1.925 & .928 & 1 & .928 & الإستعداد الدائم للتعلم المستمر & \\
\hline .241 & 1.377 & .753 & 1 & .753 & مسؤولية الإقدام على المخاطر & \\
\hline
\end{tabular}




\begin{tabular}{|c|c|c|c|c|c|c|}
\hline الإحصائية & قالمحسوبة فيمة & مجوسط & الحرجة & 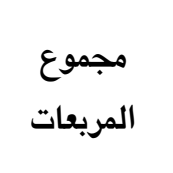 & الت المتفير & 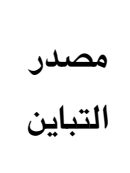 \\
\hline .019 & 5.567 & 1.776 & 1 & 1.776 & 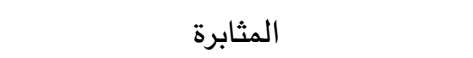 & \\
\hline .000 & 13.741 & 4.264 & 1 & 4.264 & التفكير والتواصل بوضوح ودقة & \\
\hline .002 & 9.916 & 11.702 & 1 & 11.702 & التحكم بالاندفاعية & \\
\hline .593 & .286 & .176 & 1 & .176 & التساؤل وطرح المشكلات & \\
\hline .001 & 12.192 & 5.456 & 1 & 5.456 & الاستجابة بدهشة ورهبة & \\
\hline .343 & .900 & .433 & 1 & .433 & التفكير بمرونة & \\
\hline .014 & 6.064 & 2.206 & 1 & 2.206 & جمع البيانات باستخدام جميع الحواس & \\
\hline .002 & 9.485 & 3.610 & 1 & 3.610 & السعي للدقة & الصف \\
\hline .065 & 3.411 & 1.210 & 1 & 1.210 & تطبيق المعارف الماضية على مواقف & الدراسي \\
\hline .006 & 7.630 & 2.943 & 1 & 2.943 & الإصفاء بتفهم وتعاطف & \\
\hline .039 & 4.296 & 11.385 & 1 & 11.385 & التفكير ما وراء المعرفي & \\
\hline .427 & .631 & .500 & 1 & .500 & إيجاد الدعابة وجو من المرح & \\
\hline .012 & 6.322 & 4.065 & 1 & 4.065 & الإبداع - التخيل والتجديد & \\
\hline .000 & 20.805 & 8.492 & 1 & 8.492 & التفكير التبادلي & \\
\hline .000 & 12.630 & 6.086 & 1 & 6.086 & الإستعداد الدائم للتعلم المستمر & \\
\hline .004 & 8.277 & 4.529 & 1 & 4.529 & مسؤولية الإقدام على المخاطر & \\
\hline .365 & .821 & .262 & 1 & .262 & المثابرة & \multirow{16}{*}{ الجنس الصف } \\
\hline .739 & .111 & .034 & 1 & .034 & التفكير والتواصل بوضوح ودقة & \\
\hline 46.0 & 4.091 & 4.828 & 1 & 4.828 & التحكم بالاندفاعية & \\
\hline .696 & .153 & .094 & 1 & .094 & التساؤل وطرح المشكلات & \\
\hline .980 & .001 & .000 & 1 & .000 & الاستجابة بدهشة ورهبة & \\
\hline .904 & .015 & .007 & 1 & .007 & التفكير بمرونة & \\
\hline .306 & 1.051 & .382 & 1 & .382 & جمع البيانات باستخدام جميع الحواس & \\
\hline .088 & 2.929 & 1.115 & 1 & 1.115 & السعي للدقة & \\
\hline .362 & .834 & .296 & 1 & .296 & تطبيق المعارف الماضية على مواقف & \\
\hline .242 & 1.371 & .529 & 1 & .529 & الإصغاء بتفهم وتعاطف & \\
\hline .241 & 1.376 & 3.646 & 1 & 3.646 & التفكير ما وراء المعرفي & \\
\hline .999 & .000 & $3.992 \mathrm{E}-7$ & 1 & $3.992 \mathrm{E}-7$ & إيجاد الدعابة وجو من المرح & \\
\hline .667 & .185 & .119 & 1 & .119 & الإبداع - التخيل والتجديد & \\
\hline .713 & .135 & .055 & 1 & .055 & التفكير التبادلي & \\
\hline .800 & .064 & .031 & 1 & .031 & الإستعداد الدائم للتعلم المستمر & \\
\hline .793 & .069 & .038 & 1 & .038 & مسؤولية الإقدام على المخاطر & \\
\hline
\end{tabular}

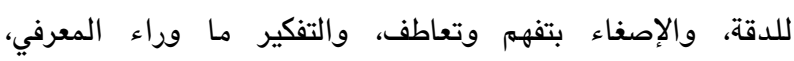

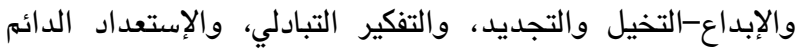

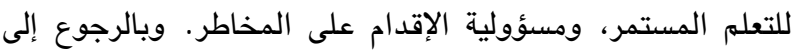

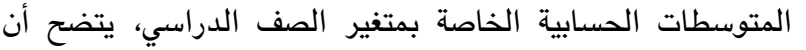

يتضح من الجدول (6) وجود فروق ذات دلالة إحصائية،

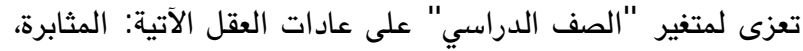

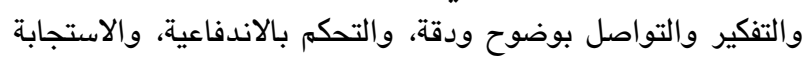
بدهشة ورهبة، وجمع البيانات باستخدام جميع الحواس، والسعي والتئ والاني 
للإجابة عن هذا السؤال، حسبت المتوسطات الحسابية

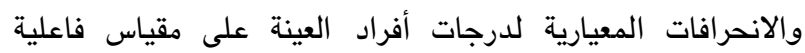

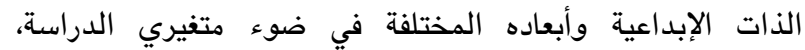

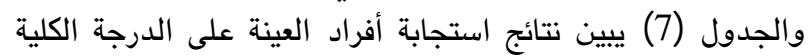
لمقياس فاعلية الذات الإبداعية تبعًا لمتغيري الدراسة.
الفروق كانت دالة إحصائيًا على جميع هذه العادات لصالح طلبة

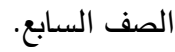
نتائج السؤال الثاني: هل توجد فروق دالة إحصائيًا (م=0.05=

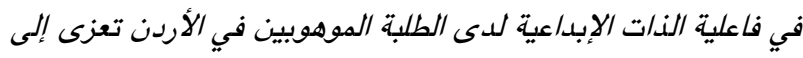

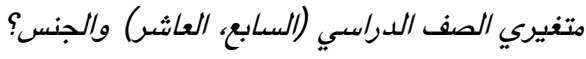

جدول(7): المتوسطات الحسابية والانحرافات المعيارية لاستجابة أفراد العينة على الدرجة الكلية لمقياس فاعلية الذات الابداعية تبعًا لمتفيري

الدراسة

\begin{tabular}{|c|c|c|c|c|}
\hline الانحراف المعياري & المتوسط الحسـابي & العدد & الصف & الجنس \\
\hline .507 & 4.10 & 169 & السـابع & \multirow{2}{*}{ ذكر } \\
\hline .479 & 4.01 & 63 & العاشر & \\
\hline .516 & 4.31 & 116 & السـابع & \multirow{2}{*}{ انثى } \\
\hline .458 & 4.07 & 72 & العاشر & \\
\hline
\end{tabular}

يتضح من الجدول (7) وجود فروق ظاهرية بين المتوسطات تحليل التباين الثنائي (2-Way ANOVA) للدرجة الكلية.

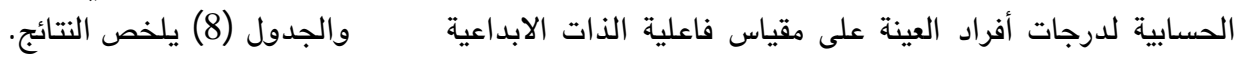

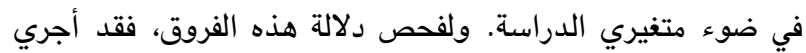

جدول(8): تحليل التباين الثنائي لاستجابة أفراد العينة على مقياس فاعلية الذات الإبداعية في ضوء متغيري الدراسة

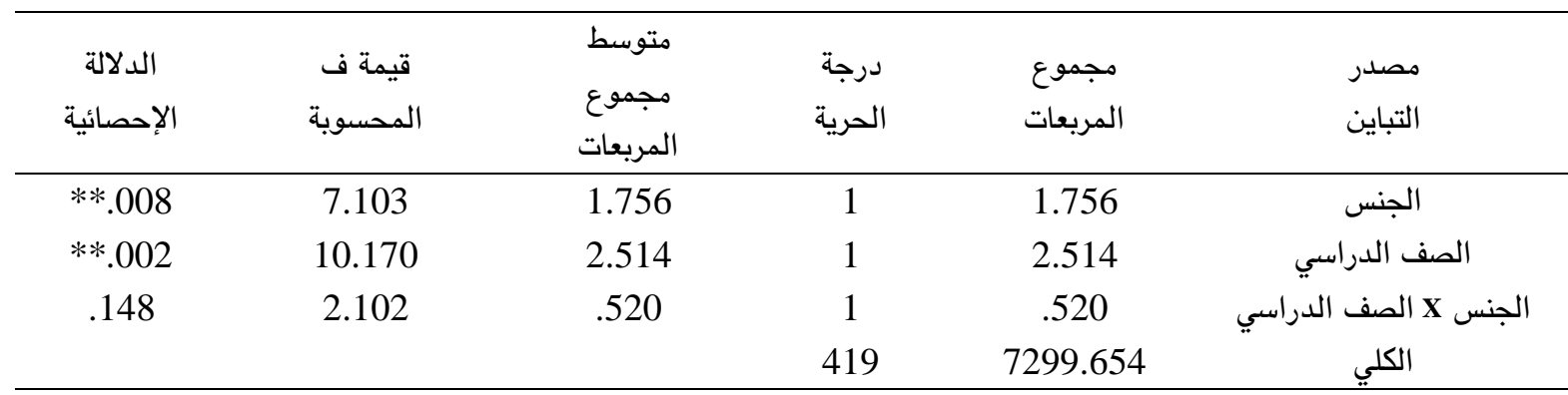

والصف السابع. في حين له تظهر أية فروقات ذات دلالة احصائية يتضح من الجدول (8) وجود فروق ذات دلالة إحصائية للتفاعل بين الجنس والصف الدراسي.

كما تم حساب المتوسطات الحسابية والانحرافات المعيارية لاستجابة أفراد العينة على أبعاد مقياس فاعلية الذات الإبداعية وفقًا

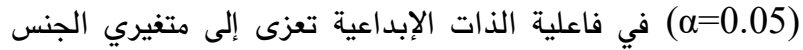

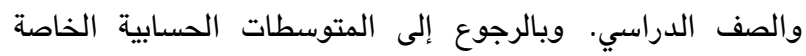
بمتغيري الجنس والصف، يظهر أن الفروق كانت لصالح فئة الإناث،

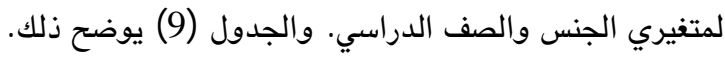

جدول (9): المتوسطات الحسابية والانحرافات المعيارية لاستجابة أفراد العينة على أبعاد مقياس فاعلية الذات الإبداعية وفقًا لمتغيري الجنس والصف الدراسي.

\begin{tabular}{|c|c|c|c|c|c|c|c|}
\hline \multicolumn{6}{|c|}{ الجنس } & \multirow{3}{*}{ الصف } & \multirow[b]{3}{*}{ البعد } \\
\hline \multicolumn{3}{|c|}{ الإناث } & \multicolumn{3}{|c|}{ الذكور } & & \\
\hline الانحراف المعياري & الحسوسط & العدد & الانحراف المعياري & الحستوسط الحسي & العدد & & \\
\hline .781 & 4.31 & 116 & .604 & 4.07 & 169 & السابع & فاعلية الذات في \\
\hline .504 & 4.02 & 72 & .615 & 3.98 & 63 & العاشر & التفكير الإبداعي \\
\hline .390 & 4.31 & 116 & .525 & 4.12 & 169 & السابع & فاعلية الذات في \\
\hline .473 & 4.13 & 72 & .417 & 4.03 & 63 & العاشر & الأداء الإبداعى \\
\hline
\end{tabular}


دلالة هذه الفروق، فقد تم إجراء تحليل التباين الثنائي متعدد

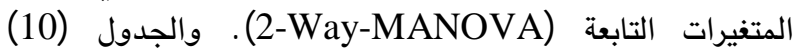

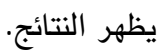

يظهر من الجدول (9) وجود فروق ظاهرية بين المتوسطات

الحسابية لأداء أفراد عينة الدراسة على أبعاد مقياس فاعلية الذات فرات

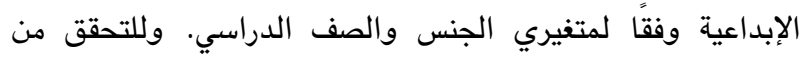

جدول (10): نتائج تحليل التباين الثنائي متعدد المتغيرات على أبعاد فاعلية الذات الإبداعية

\begin{tabular}{|c|c|c|c|c|c|c|}
\hline الإحصائية الدلالة & لدرجة & الفرضية & قالميمة ف الكلية & الاختبمة المتعدد & الاختبار & المتفير \\
\hline .013 & 415.000 & 2.000 & $4.389^{\mathrm{b}}$ & .021 & Hotelling's Trace & الجنس \\
\hline .006 & 415.000 & 2.000 & $5.129^{\mathrm{b}}$ & .025 & Hotelling's Trace & الصف الدراسي \\
\hline .317 & 415.000 & 2.000 & $1.151^{\mathrm{b}}$ & .006 & Hotelling's Trace & الجنس X الصف الدراسي \\
\hline
\end{tabular}

للتفاعل بين المتغيرين في أبعاد مقياس فاعلية الذات الابداعية.

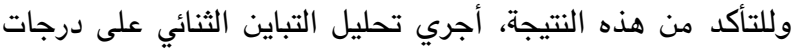

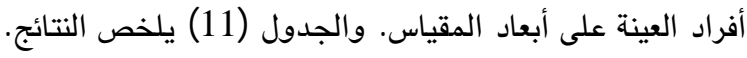

يتضح من الجدول (10) وجود فروق ذات داتلالة إحصائية

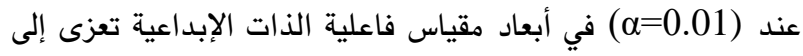

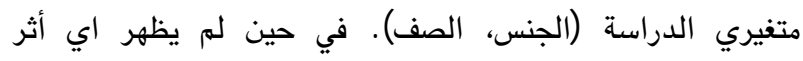
جدول (11): نتائج تحليل التباين الثنائي لدرجات أفراد العينة على أبعاد مقياس فاعلية الذات الإبداعية

\begin{tabular}{|c|c|c|c|c|c|c|}
\hline 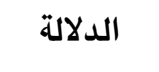 & ق & متوسط مجموع & 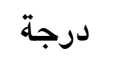 & 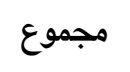 & المتفير & 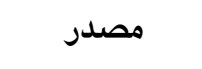 \\
\hline الإحصائية & 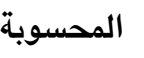 & المربعات & الحرية & 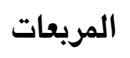 & 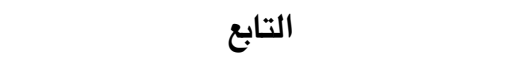 & التباين الت \\
\hline $.047^{*}$ & 3.977 & 1.653 & 1 & 1.653 & فاعلية الذات الإبداعية في التفكير الإبداعي & \multirow{2}{*}{ 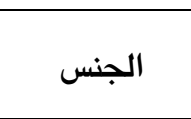 } \\
\hline $.004^{*}$ & 8.604 & 1.873 & 1 & 1.873 & فاعلية الذات الإبداعية في الأداء الإبداعي & \\
\hline $.005^{*}$ & 8.057 & 3.350 & 1 & 3.350 & فاعلية الذات الإبداعية في التفكير الإبداعي & الصف \\
\hline $.005^{*}$ & 7.925 & 1.726 & 1 & 1.726 & فاعلية الذات الإبداعية في الأداء الإبداعي & 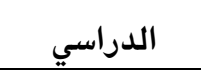 \\
\hline .131 & 2.294 & .954 & 1 & .954 & فاعلية الذات الإبداعية في التفكير الإبداعي & الجنسX|لصف \\
\hline .350 & .875 & .191 & 1 & .191 & فاعلية الذات الإبداعية في التفكير الإبداعي & الدراسي \\
\hline
\end{tabular}

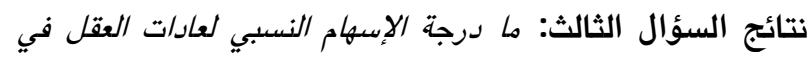

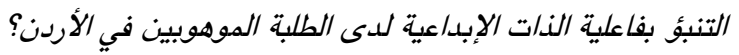

للإجابة عن هذا السؤال، استخدم معامل الانحدار المتعدد

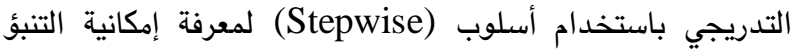
بمستوى فاعلية الذات الإبداعية لدى الطلبة البلة الموهوبين في الأردن من خلال عاداتهم العقلية، والجدول (12) يبين ذلك.
يتضح من الجدول (11) وجود فروق ذات دلالة إحصائية

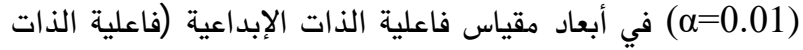

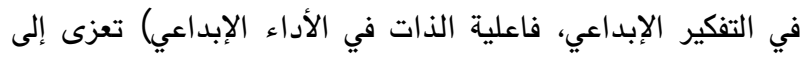

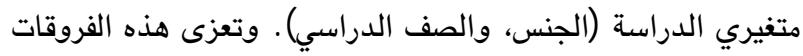

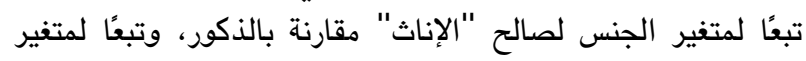

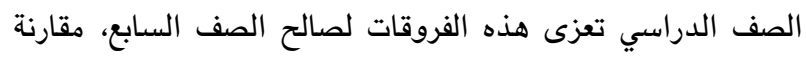


جدول (12): نتائج اختبار التنبؤ للمتغير المتنبئ ومعامل الإرتباط المتعدد له ومقدار تفسيره حسب أسلوب (Stepwise) للمتغيرات المُتَبَئة

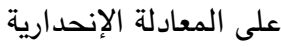

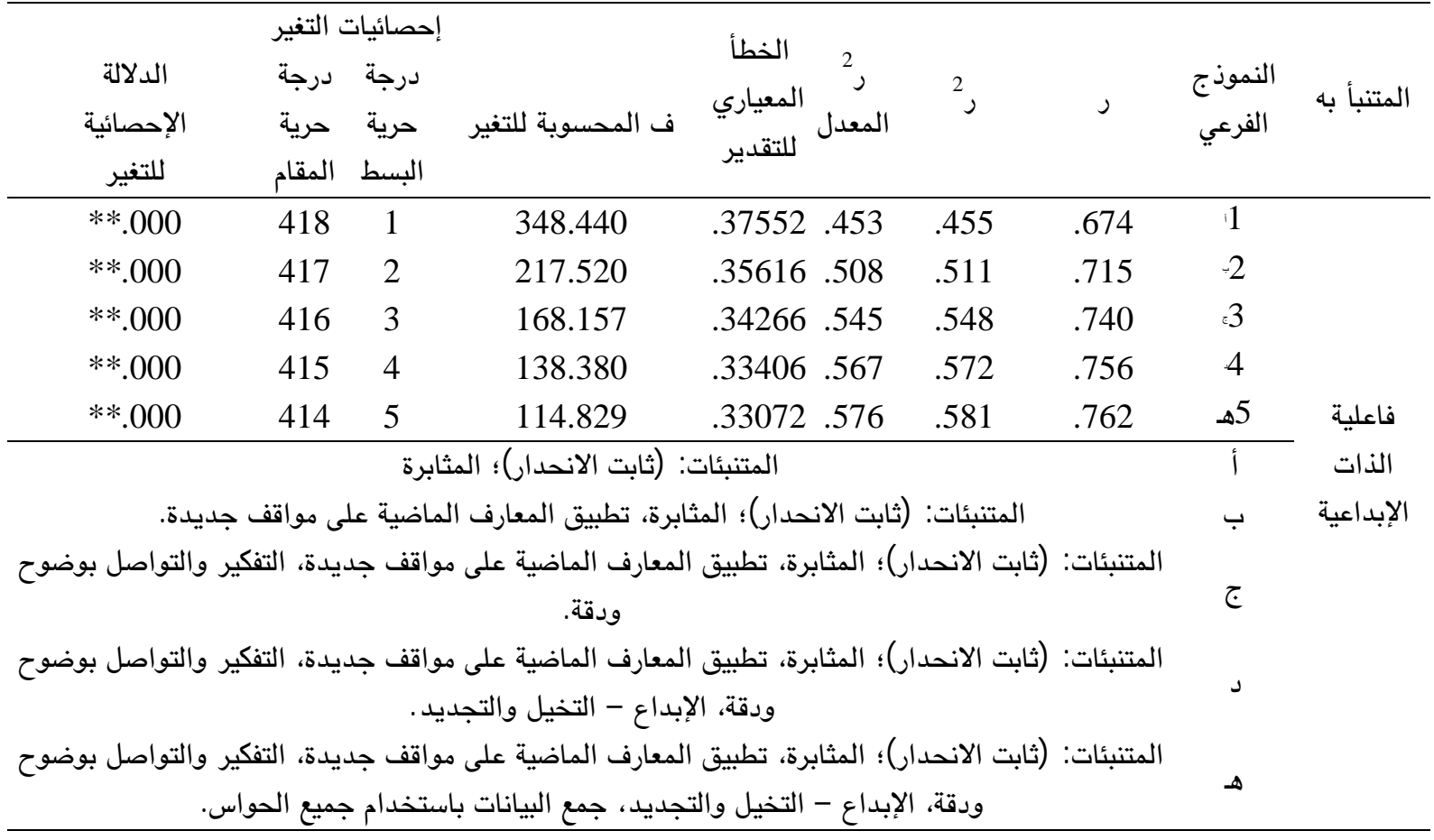

(a=0.01) بأثر نسبي مُفسرًا ما مقداره (57.2\%) من التباين

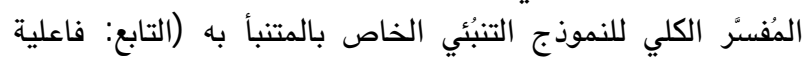

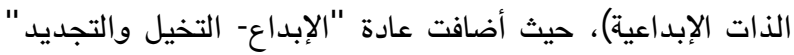

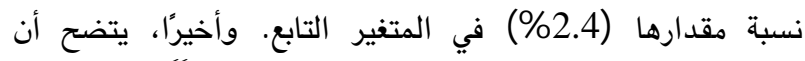

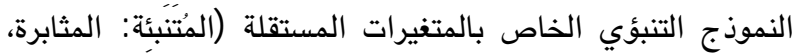
وتطبيق المعارف الماضية على مواقف جديدة، التفكير والتواصل

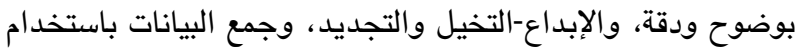

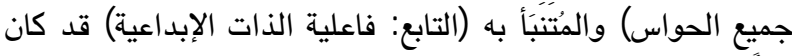

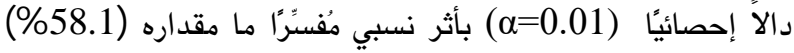

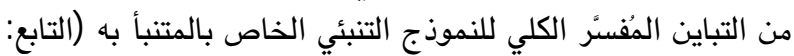

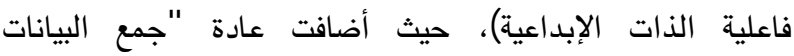

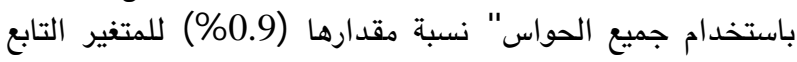

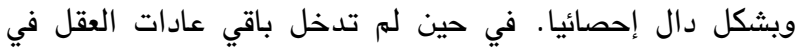

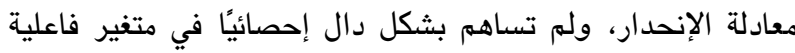

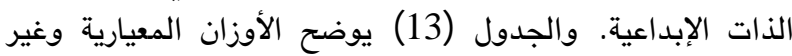
المعيارية لعادات العقل المتنبئة بمستوى فاعلية الذات الإبداعية.
يتضح من الجدول (12)، أنَ النموذج المتنبئي الخاص (فاصلئاس

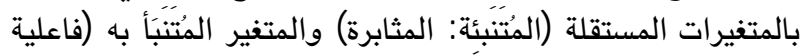

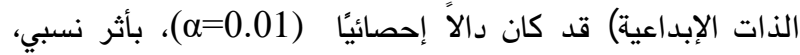

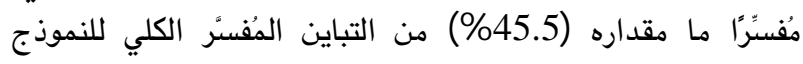

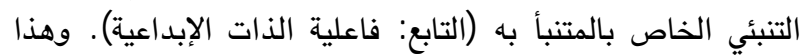

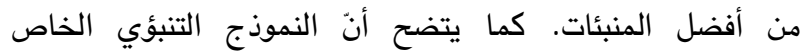

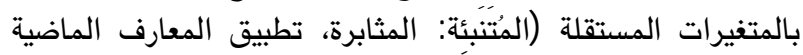

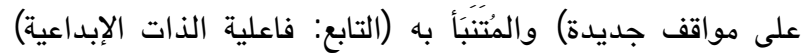

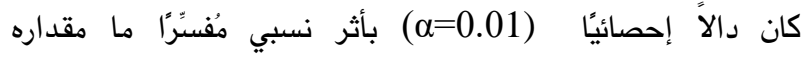

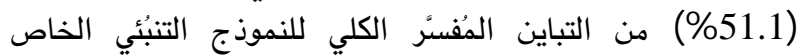

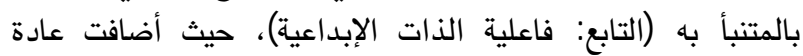

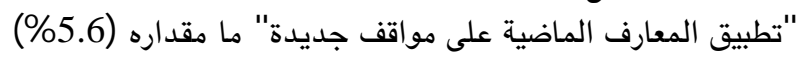

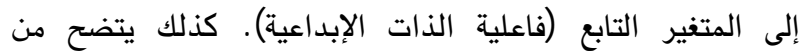

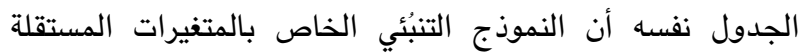

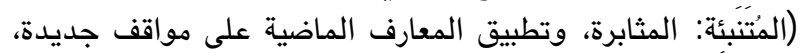

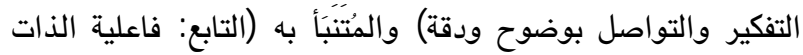

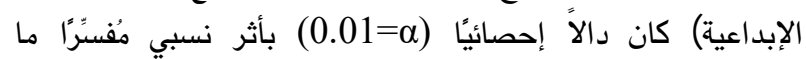

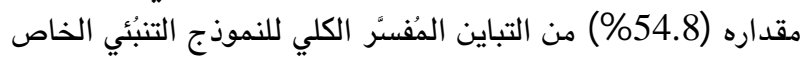

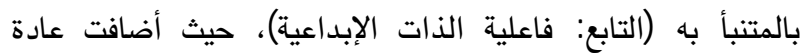

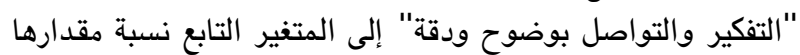
(3.7\%). أما النموذج التنبؤي الخاص بالمتفيرات التيرة المستقلة

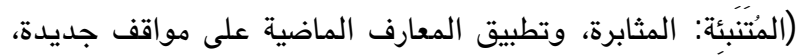

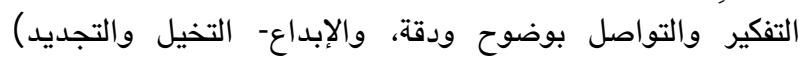

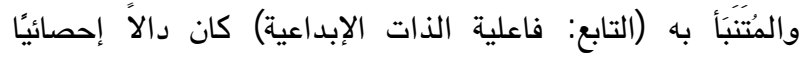


جدول (13): الاوزان المعيارية واللامعيارية لعادات العقل المتنبئة بمستوى فاعلية الذات الإبداعية

\begin{tabular}{|c|c|c|c|c|c|c|}
\hline \multirow{2}{*}{ الاحصائية الدلالة } & \multirow[b]{2}{*}{ ت } & الوزن المعياري & \multicolumn{2}{|c|}{ الاوزان اللامعيارية } & \multirow[b]{2}{*}{ عادات العقل المتنبئة } & \multirow[b]{2}{*}{ النموذج } \\
\hline & & 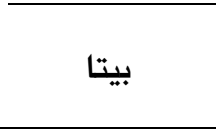 & المعياري & 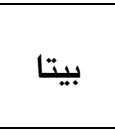 & & \\
\hline .000 & 10.264 & & .144 & 1.476 & (Constant) & i \\
\hline .000 & 18.667 & .674 & .032 & .602 & المثابرة & \\
\hline .000 & 5.583 & & .160 & .895 & (Constant) & \\
\hline .000 & 16.564 & .597 & .032 & .533 & المثابرة & \\
\hline .000 & 6.905 & .249 & .031 & .211 & تطبيق المعارف الماضية على مواقف جديدة & $\varphi$ \\
\hline .004 & 2.865 & & .169 & .485 & $($ Constant $)$ & \\
\hline .000 & 13.908 & .518 & .033 & .462 & المثابرة & \\
\hline .000 & 6.899 & .239 & .029 & .203 & تطبيق المعارف الماضية على مواقف جديدة & ج \\
\hline .000 & 5.873 & .211 & .032 & .189 & التفكير والتواصل بوضوح ودقة & \\
\hline .014 & 2.473 & & .166 & .410 & (Constant $)$ & \\
\hline .000 & 11.863 & .456 & .034 & .407 & المثابرة & \\
\hline .000 & 5.747 & .200 & .030 & .170 & تطبيق المعارف الماضية على مواقف جديدة & 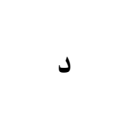 \\
\hline .000 & 5.975 & .209 & .031 & .187 & التفكير والتواصل بوضوح ودقة & \\
\hline .000 & 4.766 & .174 & .023 & .110 & الإبداع - التخيل والتجديد & \\
\hline .048 & 1.982 & & .166 & .329 & (Constant) & \\
\hline .000 & 10.779 & .425 & .035 & .379 & المثابرة & \\
\hline .000 & 4.635 & .167 & .031 & .142 & تطبيق المعارف الماضية على مواقف جديدة & \\
\hline .000 & 5.369 & .189 & .032 & .170 & التفكير والتواصل بوضوح ودقة & $ه$ \\
\hline .000 & 4.571 & .166 & .023 & .105 & الإبداع - التخيل والتجديد & \\
\hline .002 & 3.068 & .118 & .032 & .098 & جمع البيانات باستخدام جميع & \\
\hline
\end{tabular}

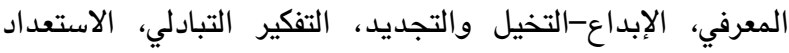

مناقشة النتائج

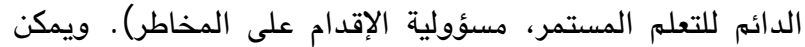

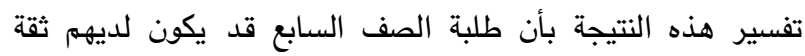

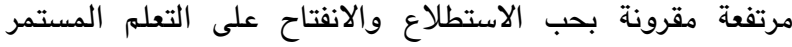

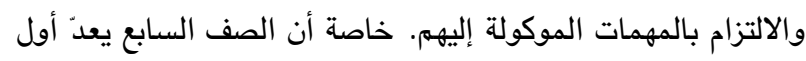

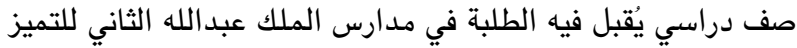

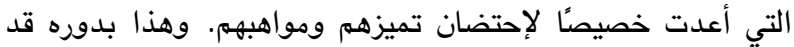

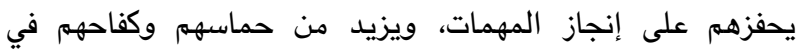
توصيل ما يفكرون ويشعرون به ويريدون قوله بدقة باستخدام

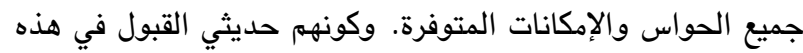

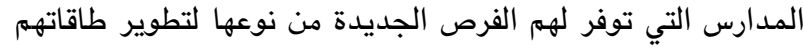

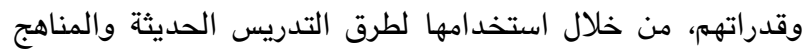

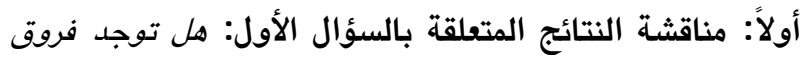

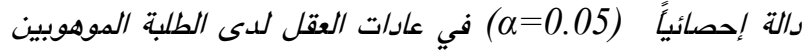

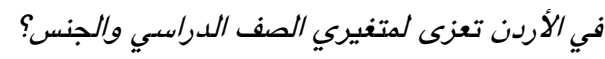

أشارت نتائج هذا السؤال إلى عدم وجود فروق دالة إحصائيًا

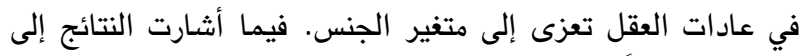

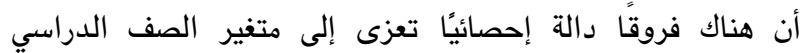

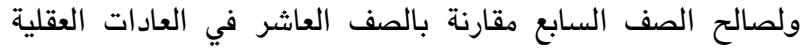

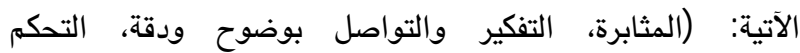

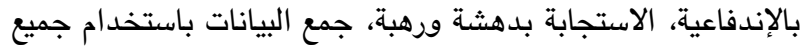
الحواس، السعي للدقة، الإصفاء بتفهم وتعاطف، التفكير ما وراء 


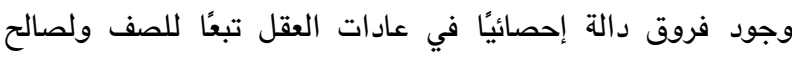

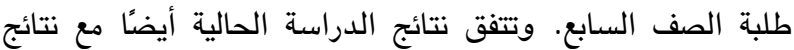

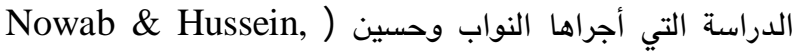

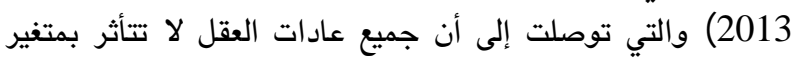

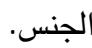

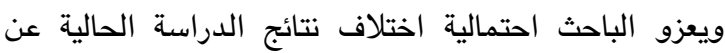

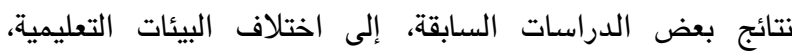

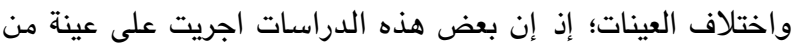

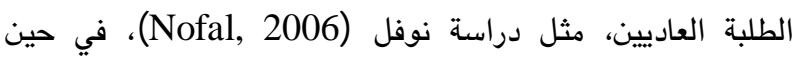

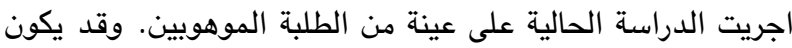

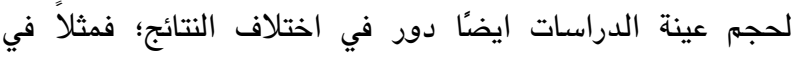
دراسة حجات (Hajjat, 2008) كان حجم العينة (1000) طالبًا وطالبة، بينما كان حجم العينة في الدراسة الحالية (420) طالئًا

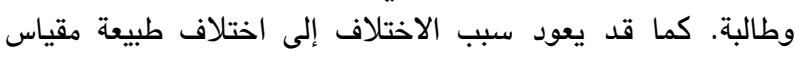

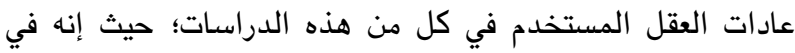
بعض هذه الدراسات كان مقياس عادات العن العقل من إعداد الداد العاد الباحث

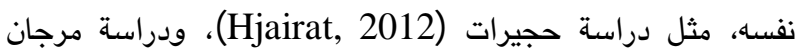
والقضاة (Morgan \& Qudah, 2016)، في حين أن الدراسة الحالية استخدمت مقياس عادات العقل بصورته الاصلية.

ثانيًا: مناقشة النتائج المتعلقة بالسؤال الثاني: هل توجد فروق لـاني

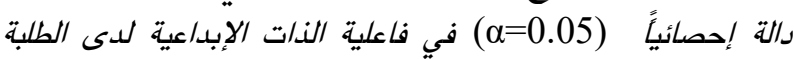

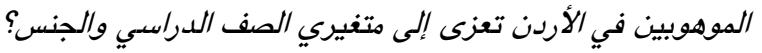

أشارت نتائج هذا السؤال إلى وجود فروق ذات دلالة إحصائية

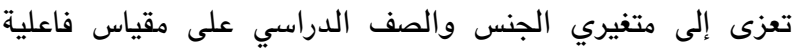

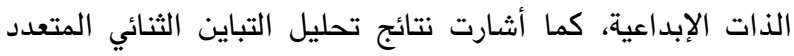

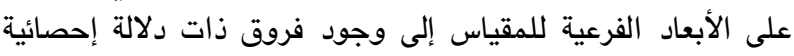

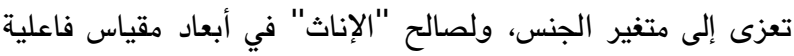

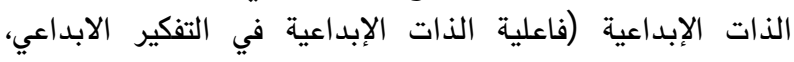

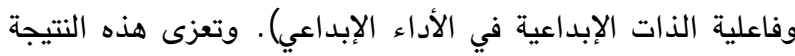

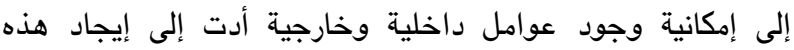

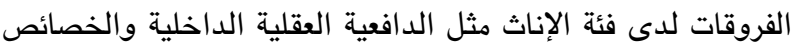

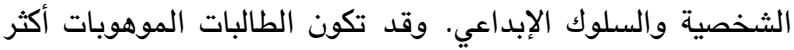

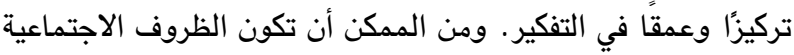

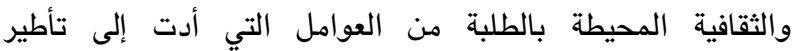

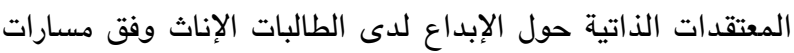

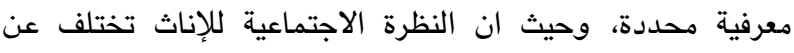
النظرة الاجتماعية للذكور، هذا قد يجعلهن أكثر دافعية للبحث عن الإنات

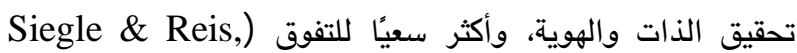

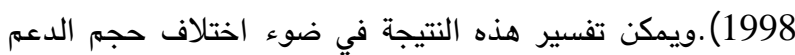
المقدم من الأهل للطالبات الإناث مقارنة بالذكور .
الإثرائية والأنشطة المنهية واللامنهجية وغيرها، فإن هذا قد

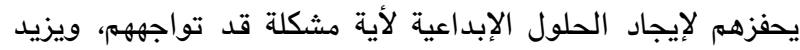

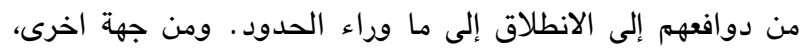

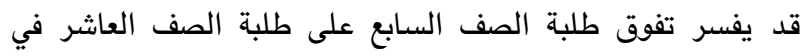

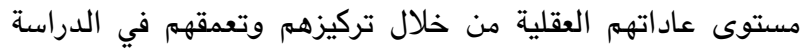

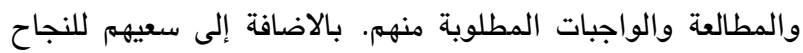

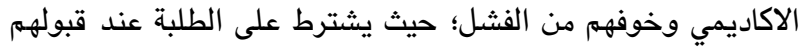

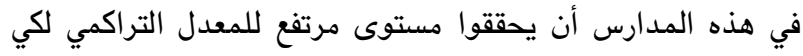

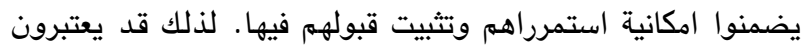

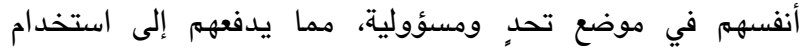
عاداتهم العقلية بشكل أكثر فاعلية، لتحقيق أهدافهم.

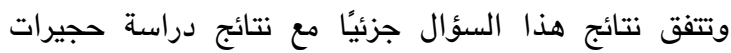

(Hjairat, 2012)

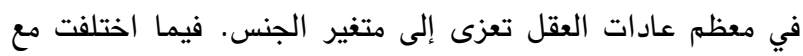

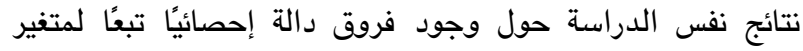

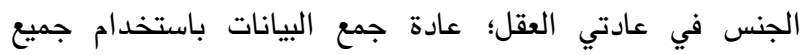

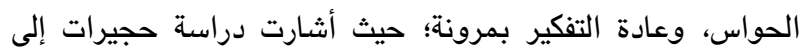

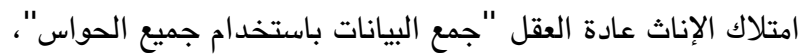

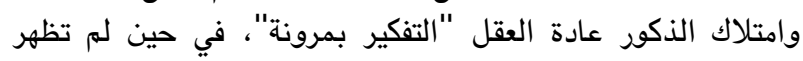

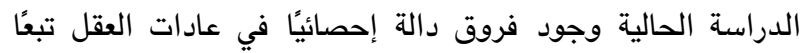

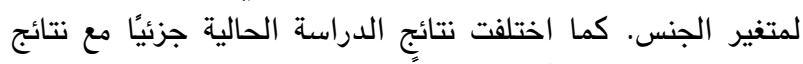

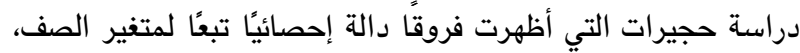

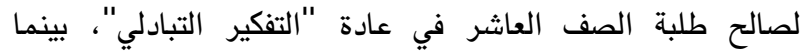

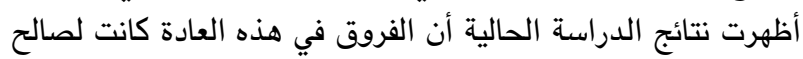

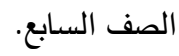

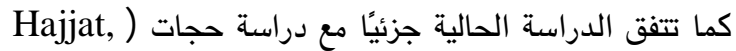
2008) في عدم وجود أثر لمتغير الجنس في معظم عاد الدادات العقل.

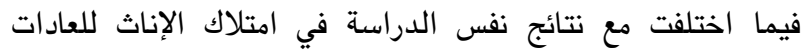

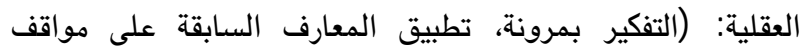

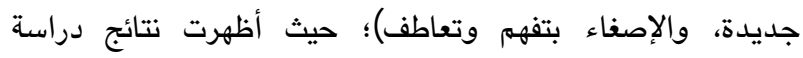

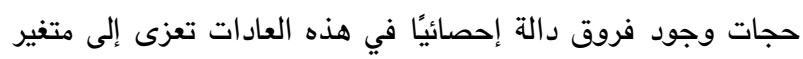

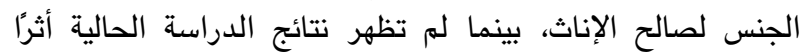

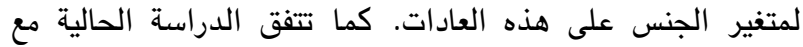
نتائج دراسة مرجان والقضاة (Morgan \& Qudah, 2016) بوجود فروق دالة إحصائيًا في عادة التحكم بالاندفاعية لصالح طلبة

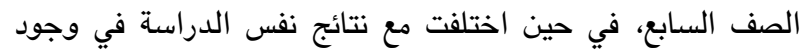

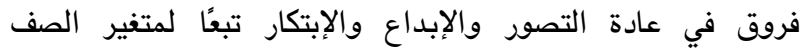

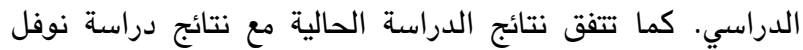
(التي توصلت الى عدم وجود فروق دالة إحصائيًا

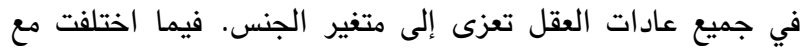

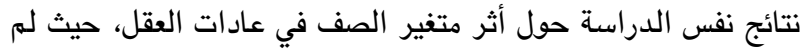

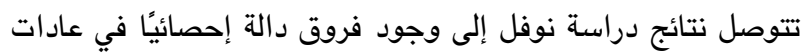
العقل تبعًا للصف الدراسي، بينما أظهرت نتائج الدراسة الحالية فئي 


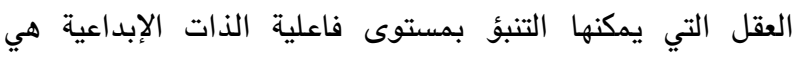

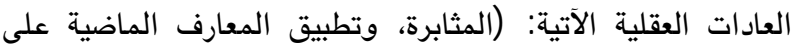

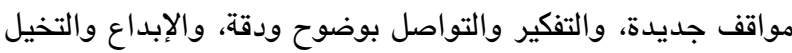

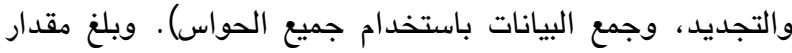

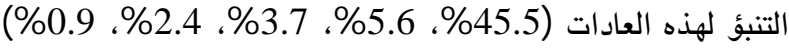

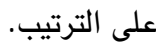

ويقصد بهذه النتيجة أن الطالب الموهوب الذي يملك درجة

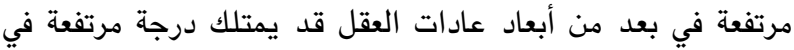

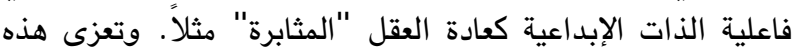
النتيجة إلى أن عادات العقل وفاعلية الذات الإبداعية تمثل عمليات

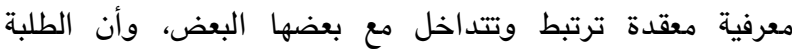

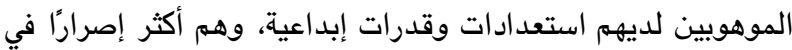

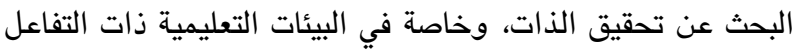

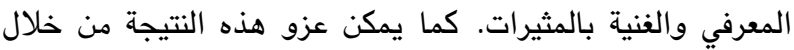

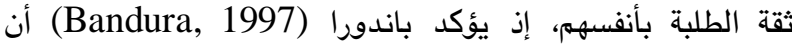

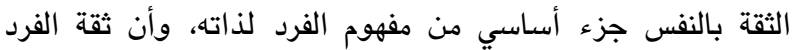

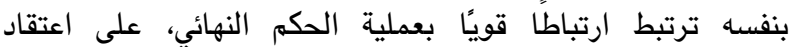

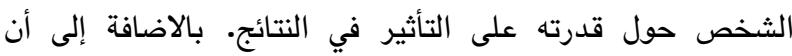
الطالب الموهوب لديه دافعية عقلية للإندماج بقوة في المهمات، فهو

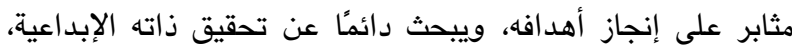
من خلال استخدام مخزونه المعرفي وتفكيره، وتوظيف حواسها المختلفة لتحقيق أهدافه الإبداعية. كما قد يكون سبب الإلهي الإسهام

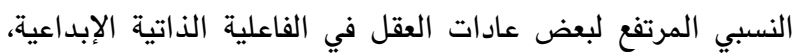
نظرًا لما يلقاه الطلبة الموهويون من تلبية مختلف حاجاتهاتهم الإنفعالية والإجتماعية والأكاديمية في بيئة مدرسية إيجابية فاعلة،

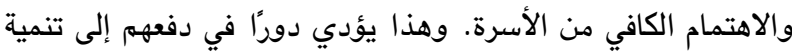

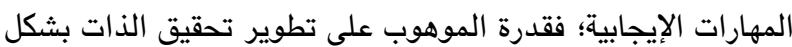
طبيعي تتحقق عندما تتوافر له بيئة مناسبة. ويمكن عزو نتيجة تقدم عادة المثابرة في التنبؤ بمستوى الإي

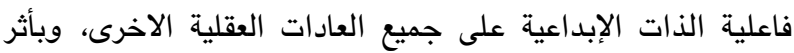

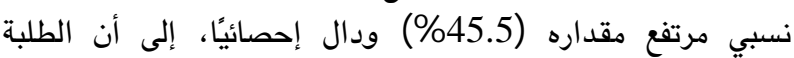

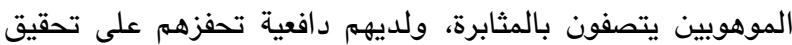

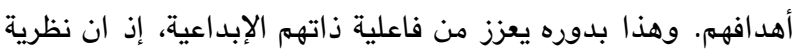

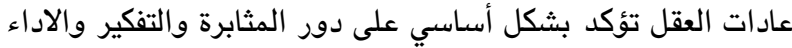
الإبداعي التي تنعكس إيجابًا على المعتقدات الدات الذاتية لدى الدى الفرد.

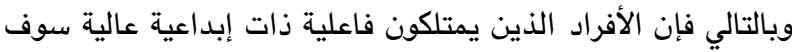

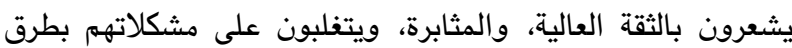

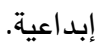

وتتفق نتائج الدراسة الحالية مع نتائج دراسة النواب وحسين

التي توصلت الى أن عادات (Nowab \& Hussein, 2013)

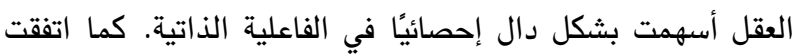

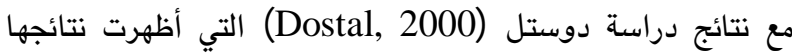
وجود علاقة موجبة قوية بين عادات العقل والتحصيل الدراسي.
وأشارت نتائج هذا السئال أيضًا إلى وجود فروق ذات دلالة

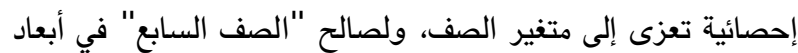

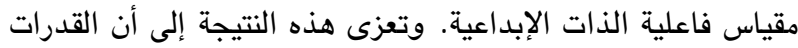

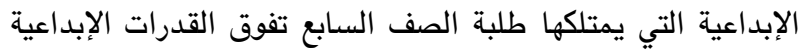

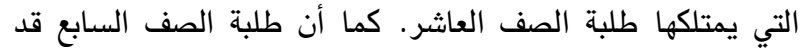

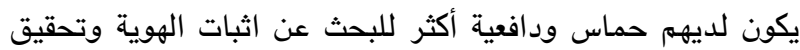

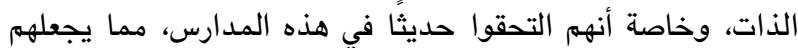

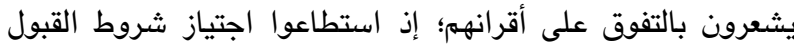

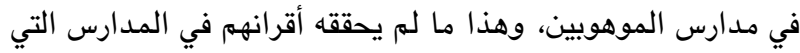
جاءوا منها. كما قد يكون للتعزيز المقدم من الأهل والمعلمين،

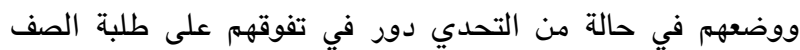

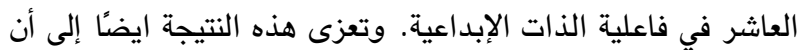

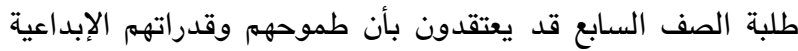

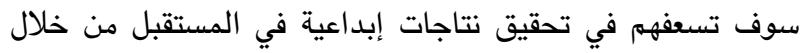

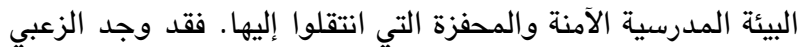
(Zoubi, 2014)

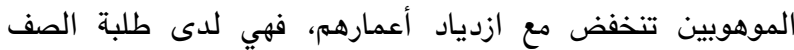

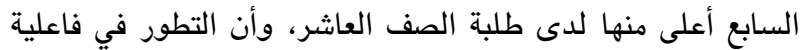

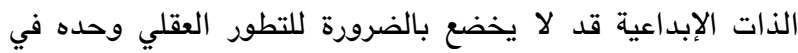
هذا الصف، بقدر تأثره بالمحيط الاجتماعي والإنجاز الثخصي وخصائص مرحلة المراهقة. كما وجد جيبس (Gibbs, 2009) أن الن الأني التقدم بالعمر ينقص من فاعلية الذات الإبداعية.

وتتفق نتائج هذا السؤال جزئيًا مع نتائج دراسة الزعبي

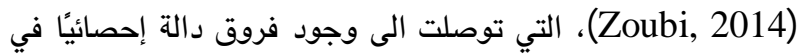

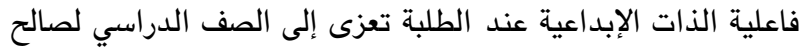

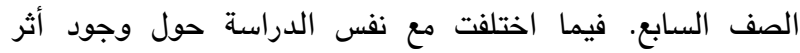

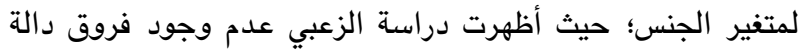

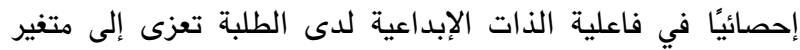

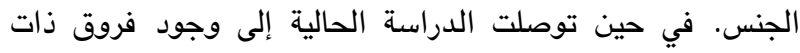

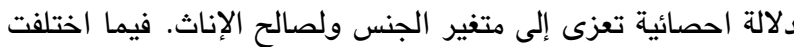

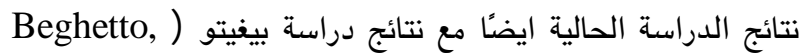

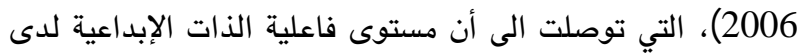

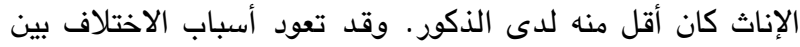

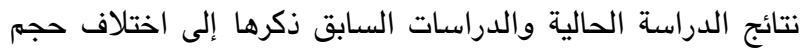
العينات، واختلاف مجتمع الدراسة، واختلاف البيئات الثقافية. ثالثًا: مناقشة النتائج المتعلقة بالسؤال الثالث: ما درجة الإسهام النسبي لعادات العقل في التنبؤ بفاعلية الذات الإبداعية لدى الطلبة

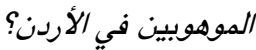

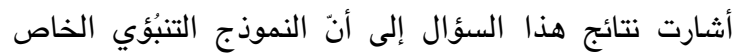

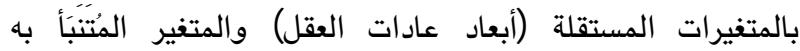
(فاعلية الذات الإبداعية) قد كان دالاً إحصائيًا (

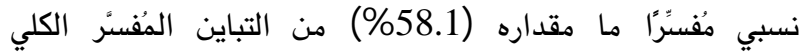

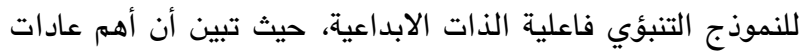


Costa, A. (2000). Mediating the metacognitive. developing minds: A resource book for teaching thinking. Alexandria, VA: ASCD.

Costa, A., \& Kallick, B. (2008). Learning and leading with habits of mind: 16 essential characteristics for success. Association for Supervision and Curriculum Development, VA: ASCD.

Costa, A., \& Lowery, L. (1991). Techniques for teaching thinking. CA: Critical Thinking Press and Software.

Curry, J. (2007). An investigation of the relationship between counseling self efficacy and counselor wellness among counselor education students. Unpublished Ph.D. Dissertation, University of Central Florida Orlando: Florida.

Dostal, P. (2000). An examination of explanatory style and habits of the mind as correlates of academic achievement in 7 th grade gifted students. M. A. Thesis, California State University, CA.

Garwan, F. (2015). Talent and excellence. Amman: Dar Al-Fikr for Publishing and Distribution.

Gibbs, S. (2009). Exploring the influence of task specific self-efficacy on opportunity recognition perspectives and behaviors. Frontiers of Entrepreneurship Research, 29(6), 1-15.

Hajjat. A. (2008). The habits of mind and selfefficacy among students of 7 th and 10th grades in Jordan and their association with some demographic variables. Doctoral Dissertation, Amman Arab University, Amman, Jordan.

Hjairat, Y. (2012). The habits of mind and its relation to multiple intelligences. Master Thesis, Amman Arab University, Jordan.

Hsu, M., Sheng-Tsung, H., \& Hsueh-Liang, F. (2011). Creative self-efficacy and innovative behavior in a service setting: Optimism as a moderator. Journal of Creative Behavior, 45 (4), 258-272.

Huroub, A. (1999). Theories and programs in the privileged and talented education. Amman: Al-Shorouk House Publishing.

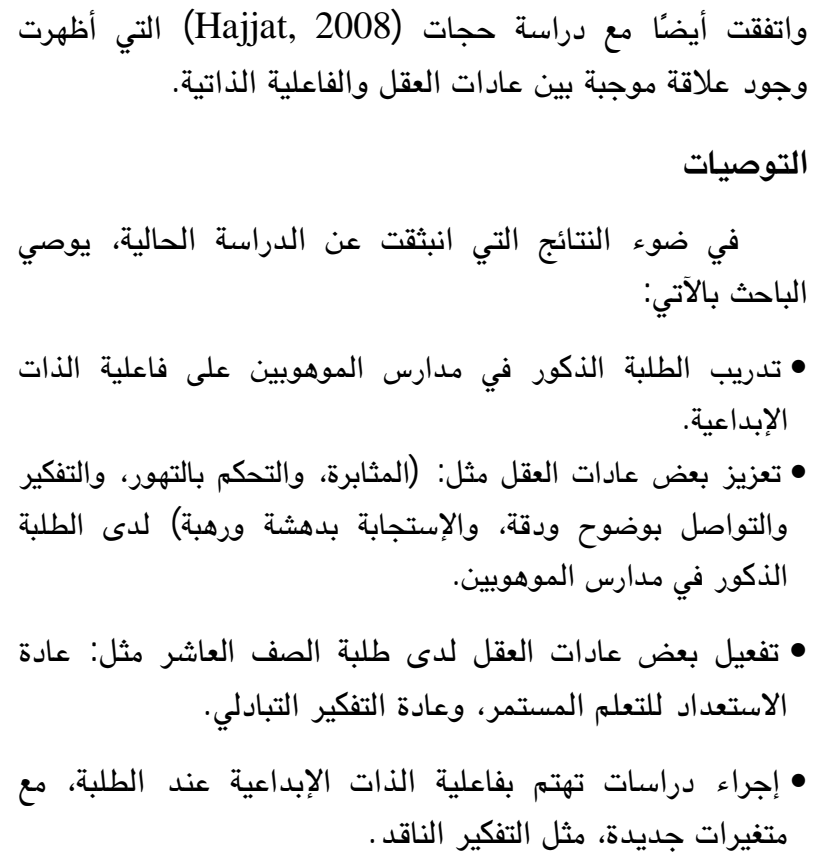

\section{References}

Abbott, D. (2010). Constructing a creative selfefficacy inventory: A mixed methods inquiry. Unpublished Ph.D. Dissertation, Nebraska University.

Adams. C. (2006). Power Point, habits of mind, and classroom culture. Curriculum Studies Journal, 38(4), 389-411.

Bandura, A. (1997). Self-efficacy The exercise of control. New York: W.H. Freeman.

Beghetto, R. (2006). Creative self-efficacy: Correlates in middle and secondary students, Creativity Research Journal, 18(4), 447-457.

Campbell, J. (2006). Theorizing habits of mind as a framework for learning. Paper presented at the Australian Association for Research in Education (AARE) Annual Conference Adelaide, Central Queensland University. Retrirved from: https://www.aare.edu.au/data/ publications/2006/cam06102.pdf

Chin, Y. (2013). The relationship between undergraduate students' creative self efficacy, creative ability and career self-management. International Journal of Academic Research in Progressive Education and Development, 2(2), 181-193.

Clark, B. (2008). Growing up giftedness (7th ed.). New York: Macmillan Publishing Company. 
Maciej, K. (2012). Did curiosity kill the cat? Relationship between trait curiosity, creative self-efficacy and creative personal identity. Europe's Journal of Psychology, 8(4), 547558.

Mathisen, G., \& Bronnick, K. (2009). Creative self-efficacy: An intervention study, International Journal of Educational Research. 48, 21-29.

Morgan, R., \& Qudah, M. (2016). The relative contribution of the habits of mind to predict the emotional intelligence of basic and secondary students in the city of Ibb, Yemen. International Journal of Excellence Development - Yemen,13(7), 27- 54.

Nofal, M. (2006). Common habits of mind among elementary school students in UNRWA schools in Jordan. Journal of the Student Teacher (UNRWA / UNESCO). 1, 33-75.

Nofal, M. (2010). Practical applications in the development of thinking using the habits of mind. Amman: Dar Al-Maseera House.

Nowab, N., \& Hussein, M. (2013). Habits of mind and thinking of high rank and their relation to the self-efficacy of students of faculties of education. Journal of Human Sciences, 19, 149-172.
Phelan, S. (2001). Developing creative competence at work: The reciprocal effects of creative thinking, self-efficacy and organizational culture on creative performance. Dissertation Abstracts International, 62(2), 10-59.

Qatami, Y. (2007). Thirty mental habits. Amman: De Bono Center For Teaching Thinking.

Shih-Ching, S., Shy-Yi, L. (2012). The relationship between learning motivation and innovative behavior on the university students form the perspective of creative self-efficacy. International Journal of Arts \& Sciences, 5(5), 33-38.

Siegel, D., \& Reis, S. (1998). Gender differences in teacher and student per-ceptions of gifted students' abiliyty and effort. Gifted Children Quarterly, 4(2), 39-47.

Sternberg, R. (1997). Successful intelligence. New York: Plume.

Tierney, P., \& Farmer, S. (2002). Creative selfefficacy: Its potential antecedents and relationship to creative performance. Academy of Management Journal, 4(5), 1137-1148.

Zoubi, A. (2014). The creative self-efficacy of gifted students and their teachers in Jordan. Jordan Journal of Educational Sciences, 10(4), 475-488. 